\title{
Surgical management of renal cell carcinoma: Canadian Kidney Cancer Forum Consensus
}

\author{
Ricardo A. Rendon, MD, FRCSC;, Anil Kapoor, MD, FRCSC; ; Rodney Breau, MD, FRCSC;; Michael Leveridge, \\ MD, FRCSC,; Andrew Feifer, MD, FRCSC,: Peter C. Black, MD, FRCSC,; Alan So, MD, FRCSC,; on behalf of the \\ Kidney Cancer Research Network of Canada
}

*Department of Urology, Dalhousie University, Halifax, NS; 'Department of Surgery, Division of Urology, McMaster University, Hamilton, ON; §Division of Urology, University of Ottawa, Ottawa, ON; *Departments of Urology and Oncology, Queen's University, Kingston, ON; : Credit Valley Hospital, Mississauga, ON; BDepartment of Urologic Sciences, University of British Columbia, Vancouver, BC

Cite as: Can Urol Assoc J 2014;8(5-6):e398-412. http://dx.doi.org/10.5489/cuaj.1894 Published online June 19, 2014.

\section{Epidemiology}

The Canadian Cancer Society estimated 5900 new cases of renal cell carcinoma (RCC) and 1750 related deaths in Canada in 2012. ${ }^{1}$ RCC is the sixth and eleventh most common cancer diagnosed in Canadian men and women, respectively, and its incidence has been rising by about $2.3 \%$ per year, including the period from 2005 to 2009. ${ }^{2}$ Much of this rise is attributed to incidental detection via abdominal imaging for other causes. Most of these RCCs have been small renal masses (SRMs), defined as solid-appearing masses less than $4 \mathrm{~cm}$ in maximum diameter. ${ }^{3,4}$

Hereditary RCC syndromes are well-described, but account for a minority of incidental findings. Other wellrecognized risk factors include cigarette smoking, obesity, hypertension and chronic renal failure..$^{5-7}$

\section{Evaluation}

\section{Primary evaluation and investigations}

\footnotetext{
- Thorough history

- Physical examination

- Laboratory evaluation

o Complete blood count $(\mathrm{CBC})$, renal function

o Liver function (transaminases)

o Markers of bone disease (alkaline phosphatase and corrected calcium)

o Markers of prognosis in patients with advanced disease (Lactic acid dehydrogenase [LDH], platelets, calcium, neutrophils, hemoglobin)

o Urine cytology in central tumours
}

The initial evaluation of patients with RCC begins with a thorough medical history. Within the history, the identification of risk factors for RCC should be assessed, including history of smoking, hypertension, previous renal masses, as well as a family history of renal tumours or genetic disorders associated with RCC. You should also assess the patient's symptoms, including pain (bony and flank) and gross hematuria. New onset coughing or other respiratory issues may suggest pulmonary metastases and new neurologic symptoms may suggest cerebral metastases. The performance status should be evaluated.

Physical examination should include blood pressure, as well as abdominal examination for masses and assessment for cervical lymphadenopathy and lower extremity edema, which may suggest inferior vena cava (IVC) involvement. Neurologic exam should be performed if there is any suggestion of cerebral or spinal metastases.

Laboratory evaluation includes a complete blood count $(\mathrm{CBC})$, and renal function studies (creatinine, estimated glomerular filtration rate [eGFR]). Liver function testing (alanine transaminase $[\mathrm{ALT}]$, aspartate aminotransferase [AST]) and markers of bony disease (serum alkaline phosphatase and corrected calcium) should also be assessed. ${ }^{8}$ In patients with advanced disease, laboratory features that are associated with worse overall survival include anemia, hypercalcemia, neutrophilia, thrombocytosis, and elevated LDH. ${ }^{9}$ For central masses, urine cytology may be valuable to differentiate urothelial cell carcinoma from RCC. 


\section{Staging}

- Primary tumour:

o Triphasic abdominal/pelvic computed tomography (CT) without and with intravenous contrast.

o Abdominal magnetic resonance imaging (MRI), if contrast allergy or renal insufficiency or CT suggests caval thrombus and level cannot be determined.

o Consider Doppler ultrasound to assess the extent of tumour involvement of the IVC.

- Metastatic evaluation

o Chest X-ray, consider CT chest if $\geq$ stage T2.

o Bone scan, if clinically indicated or elevated alkaline phosphatase and serum calcium.

o Brain CT or MRI if large volume metastatic disease.

\section{Radiologic examination and staging}

With staging accuracy of over 90\%, CT imaging is the imaging of choice of renal masses. ${ }^{10,11}$ Enhancement of renal tumours, defined as an attenuation increase of 10 to 20 Hounsfield units (HU) on post-contrast images, is an important determinant of the malignant potential of a renal mass. ${ }^{12}$ The evaluation of CT image includes staging of the primary tumour, determination of Iymphadenopathy, abdominal metastatic disease and characterization of the contralateral kidney. Abdominal MRI is an alternative to assess renal masses for pregnant patients and those with a contrast allergy, and decreased renal function. As well, MRI is another tool to evaluate IVC tumour involvement with a sensitivity of almost $100 \% .^{13}$ Doppler ultrasound is also a valuable tool to determine the extent of tumour involvement of the IVC. ${ }^{14}$

A chest imaging with chest $x$-ray to determine metastases is usually adequate, but a chest CT may be useful in patients who are symptomatic or are at high risk of metastases (>stage T2). In patients with compromised renal function, bilateral or multifocal disease, an isotope renogram may be useful for surgical planning and patient counselling. Moreover, patients with bony pain or elevated alkaline phosphatase and/or serum calcium should receive a bone scan to rule out bony metastases. A CT or MRI of the head may be valuable in patients with suspicion of brain metastases in cases with neurologic symptoms or large volume metastatic disease. Although positron emission tomography (PET) has no role in the primary assessment of RCC, its role in advanced RCC and assessment of tumour recurrence is evolving. ${ }^{15-17}$

\section{Bosniak Classification of renal cysts}

Initially described in 1986, the Bosniak Classification of renal cystic lesions is still used to ascertain the risk of malignancy. ${ }^{18}$ A CT or MRI can be used to classify renal cystic lesions as per the Bosniak Classification. ${ }^{19}$

Category I cysts are simple benign cyst with a hairline thin wall that does not contain septa, calcification or solid components. It measures as water density and does not enhance with contrast material. These cysts do not need follow-up. ${ }^{19}$

Category II cysts are benign cysts that might contain a few hairline thin septa. Fine calcifications might be present in the wall or septa. These cysts also include uniformly high-attenuation lesions (hyperdense cyst) of $<3 \mathrm{~cm}$ that are sharply marginated and do not enhance. These cysts do not need follow-up. ${ }^{19}$

Category IIF cysts might contain more hairline thin septa. Minimal enhancement of a hairline thin septum or wall can be seen and there might be minimal thickening of the septa or wall. These cysts might contain calcification that might be nodular and thick, with no contrast enhancement. There are no enhancing soft-tissue elements. Totally intrarenal non-enhancing high-attenuation renal lesions of $\geq 3 \mathrm{~cm}$ are also included in this category. These lesions are generally well-marginated. Between every 6 to 12 months, these cysts require follow-up with ultrasound or CT to ensure stability of solid components. ${ }^{20,21}$ Risk of malignancy with Category IIF cysts is less than $10 \% .^{22}$

Category III and IV cysts both enhance and carry a much greater risk of harbouring RCC. Category III cysts contain thickened irregular or smooth walls or septa in which measurable enhancement is present. Close to $65 \%$ of these cysts may be benign, and can include hemorrhagic cysts, chronic infected cysts, and multi-loculated cystic nephroma. ${ }^{18}$ Category IV cysts have all the criteria of category III and also contain enhancing soft-tissue components independent of the septum. ${ }^{18}$ These cysts are usually malignant (92\%) and require treatment. ${ }^{23}$

\section{Pretreatment prediction of tumour histology}

\section{Predictive tools}

- Nomograms and Classification trees may be used to predict pretreatment histology of renal masses less than $4 \mathrm{~cm}$ in diameter.

Although most renal masses $>4 \mathrm{~cm}$ are malignant, determining the cancer risk of smaller tumours can be challenging (Table 1, Table 2, Table 3, Table 4). ${ }^{24-26}$ Several authors have constructed statistical tools to predict benign and malignant histology in SRMs to aid providers in counselling patients about treatment options. One example is a patient and disease characteristic-based classification tree with an accuracy of $89 \% .{ }^{27}$ A subsequent accuracy of $74 \%$ was maintained when classification tree was externally validated. ${ }^{28}$ The advantage of a classification tree is its ease of use, as it closely correlates with a clinicians' thought process making it more likely to be used clinically.

Other groups have developed nomograms to determine 


\begin{tabular}{|c|c|}
\hline TX & Primary tumour cannot be assessed. \\
\hline T0 & No evidence of primary tumour. \\
\hline T1 & Tumour $\leq 7 \mathrm{~cm}$ in greatest dimension, limited to the kidney \\
\hline $\mathrm{T} 1 \mathrm{a}$ & Tumour $\leq 4 \mathrm{~cm}$ in greatest dimension, limited to the kidney \\
\hline $\mathrm{T} 1 \mathrm{~b}$ & $\begin{array}{l}\text { Tumour }>4 \mathrm{~cm} \text { but not }>7 \mathrm{~cm} \text { in greatest dimension, } \\
\text { limited to the kidney. }\end{array}$ \\
\hline $\mathrm{T} 2$ & Tumour $>7 \mathrm{~cm}$ in greatest dimension, limited to the kidney \\
\hline $\mathrm{T} 2 \mathrm{a}$ & $\begin{array}{l}\text { Tumour }>7 \mathrm{~cm} \text { but } \leq 10 \mathrm{~cm} \text { in greatest dimension, limited } \\
\text { to the kidney. }\end{array}$ \\
\hline $\mathrm{T} 2 \mathrm{~b}$ & Tumour $>10 \mathrm{~cm}$, limited to the kidney. \\
\hline T3 & $\begin{array}{l}\text { Tumour extends into major veins or perinephric tissues } \\
\text { but not into the ipsilateral adrenal gland and not beyond } \\
\text { Gerota fascia. }\end{array}$ \\
\hline ТЗа & $\begin{array}{l}\text { Tumour grossly extends into the renal vein or its } \\
\text { segmental (muscle containing) branches, or tumour } \\
\text { invades perirenal and/or renal sinus fat but not beyond } \\
\text { Gerota fascia. }\end{array}$ \\
\hline T3b & $\begin{array}{l}\text { Tumour grossly extends into the vena cava below the } \\
\text { diaphragm. }\end{array}$ \\
\hline T3c & $\begin{array}{l}\text { Tumour grossly extends into the vena cava above the } \\
\text { diaphragm or invades the wall of the vena cava. }\end{array}$ \\
\hline T4 & $\begin{array}{l}\text { Tumour invades beyond Gerota's fascia (including } \\
\text { contiguous extension into the ipsilateral adrenal gland). }\end{array}$ \\
\hline
\end{tabular}

AJCC: American Joint Committee on Cancer; T: primary tumour; N: regional lymph nodes; M: distant metastasis. Taken from Edge SB, American Joint Committee on Cancer. ${ }^{24}$

\section{Table 2. AJCC TNM Staging System for kidney cancer:} Regional lymph nodes

$\begin{array}{ll}\text { NX } & \text { Regional lymph nodes cannot be assessed. } \\ \text { N0 } & \text { No regional lymph node metastasis. } \\ \text { N1 } & \text { Metastases in regional lymph node(s). }\end{array}$

AJCC: American Joint Committee on Cancer; T: primary tumour; N: regional lymph nodes; M: distant metastasis. Taken from Edge SB, American Joint Committee on Cancer. ${ }^{24}$

\section{Table 3. AJCC TNM Staging System for kidney cancer: \\ Distant metastasis

M0 No distant metastasis. \\ M1 Distant metastasis.}

AJCC: American Joint Committee on Cancer; T: primary tumour; N: regional lymph nodes; M: distant metastasis. Taken from Edge SB, American Joint Committee on Cancer. ${ }^{24}$

Table 4. AJCC TNM Staging System for kidney cancer: Anatomic stage/prognostic group

\begin{tabular}{lccl}
\hline Stage & T & N & M \\
\hline I & T1 & N0 & M0 \\
II & T2 & N0 & M0 \\
III & T1 or T2 & N1 & M0 \\
& T3 & N0 or N1 & M0 \\
IV & T4 & Any N & M0 \\
& Any T & Any N & M1
\end{tabular}

AJCC: American Joint Committee on Cancer; T: primary tumour; N: regional lymph nodes; M: distant metastasis. Taken from Edge SB, American Joint Committee on Cancer. ${ }^{24}$ the risk of benign and malignant disease for SRMs..$^{29,30}$ Lane and colleagues used age, gender, radiological size at diagnosis, symptoms at presentation and smoking history to develop a nomogram with an accuracy of $0.64 .{ }^{29}$ Kutikov and colleagues developed a nomogram using the R.E.N.A.L. nephrometry scoring system with an area under the curve (AUC) of 0.76 in predicting malignancy and 0.74 in predicting low and high grade. ${ }^{30}$ The nomogram's ability to predict tumour grade (Fuhrman) has been externally validated, ${ }^{31}$ but the nomogram predicting malignancy has not been externally validated. Mullins and colleagues used R.E.N.A.L. nephrometry scoring to predict malignancy by subdividing the score in low (4-6), intermediate (7-9) and high risk (10-12). They found that an increased risk of malignancy in intermediate and highly complex masses. ${ }^{32}$ A subgroup analysis of SRMs $(<4 \mathrm{~cm})$ showed that intermediate complex masses were more likely malignant than low and highly complex SRMs.

\section{Biopsy of the localized renal mass}

- Biopsy of SRMs for histologic characterization is an option and may guide treatment decisions.

- Biopsy of a renal mass or metastatic site in the setting of metastatic disease is important in guiding systemic therapy. In patients undergoing cytoreductive nephrectomy before systemic therapy, or surgical resection of metastatic site, a biopsy may not be necessary.

- Percutaneous biopsy is associated with a low risk of complications.

- Biopsy should be reserved for patients in whom the results might change management.

The last 15 years have seen the establishment of percutaneous biopsy in the workup of SRMs. Classical indications for renal mass biopsy include the identification of metastatic deposits, lymphomatous infiltration or an infectious etiology to an imaging abnormality; more recently, there has been a focus on the histologic determination of SRMs. Numerous series have been published that establish a diagnostic rate of between $62 \%$ and $96 \%$, with a mean of $83 \%$. ${ }^{33-40}$ The series with the highest reported yield included second biopsies after a first inconclusive biopsy. ${ }^{34}$ Among diagnostic biopsies, benign masses were identified in $20 \%$ to $42 \%$ of cases. This is congruent with surgical series assessing the histology of resected SRMs. ${ }^{41}$ The largest published series to date is from Canada, and noted an $81 \%$ diagnostic rate; and a $20 \%$ incidence of benign histology. ${ }^{34}$

Comparison to pathologic specimens is not the rule in SRM biopsy series or practice; nonetheless, the reported concordance is high. Tumour classification on biopsy has been confirmed at extirpation in $73 \%$ to $98 \%$ of cases. ${ }^{33,39,42,43}$ Concordance of Fuhrman grading between biopsy and surgical specimens has not been as robust. An identical grade may be found in $32 \%$ to $70 \%$ of cases. $33,43,44$

In the case of a non-diagnostic initial biopsy, it may be 
expected that a diagnosis can be made with repeat biopsy, and that the rate of malignancy remains high. Leveridge and colleagues found that $83 \%$ of repeat biopsies were diagnostic, and $80 \%$ of these were malignant. ${ }^{34}$ Laguna and colleagues identified cancer in $71 \%$ of repeat biopsies, and $78 \%$ of all cases with a non-diagnostic initial biopsy. ${ }^{45}$ Thus, an indeterminate initial biopsy should not be taken as reassurance regarding the malignant potential of the mass.

Safety has also been reported favourably in the literature. Since 2000, the reported complication rate has been $2.4 \% .{ }^{46}$ There has been only a single case report of biopsy tract seeding with RCC in the past decade. In this case, there was suspicion of seeding in the perirenal fat on the partial nephrectomy specimen. ${ }^{47}$ No cases of clinical recurrence or metastatic disease in a biopsy tract have been published in recent years.

It is essential to identify tumour histology in the setting of metastatic disease, both to confirm that metastatic sites represent tumour spread (and not a second primary tumour) and to classify the histologic subtype as a guide to systemic therapy. In many cases in which cytoreductive nephrectomy will have been performed, the primary histology is known and widespread metastatic disease can comfortably be assumed to be similar. If cytoreductive nephrectomy is not performed prior to planned initiation of systemic therapy, percutaneous biopsy may help to guide therapy. Poorly differentiated cancer in the renal mass or metastatic sites may occasionally present a diagnostic challenge. Abel and colleagues assessed over 400 biopsy specimens in patients with metastatic disease. ${ }^{44}$ They found that in $26.8 \%$ of cases, a biopsy of metastatic sites showed unspecified cancer that could not confirm RCC. Overall, RCC was clearly identified in only $65 \%$ of cases. This large cohort study also found $96 \%$ concordance between a diagnosis of clear cell RCC on biopsy and subsequent surgical excision.

In the setting of oligometastatic disease, the link between primary and secondary masses cannot be assumed reliably. Limited data are available with regards to the role of percutaneous biopsy in this setting.

\section{Stage T1aNOMO}

- Partial nephrectomy recommended. This can be done via open/laparoscopic/robotic procedures.

- Pure or robot-assisted laparoscopic partial nephrectomy with experienced surgeons (transperitoneal or retroperitoneal).

- Consider laparoscopic radical nephrectomy for tumours not amenable to partial nephrectomy.

- Consider probe ablation by radiofrequency (RFA) or cryotherapy in patients with high surgical risk. A biopsy should be obtained before or at the time of ablation.

- Consider active surveillance in the elderly or infirm.

\section{Treatment options}

The recommended treatment of T1a RCC has evolved with the incorporation of level-1 evidence and larger observational studies into clinical practice. Previous guidelines recommended partial nephrectomy (PN) as first-line therapy for pT1a RCC, and several recent studies also support the ongoing use of $\mathrm{PN},{ }^{48,49}$ with a growing focus on the technical feasibility of minimally invasive approaches. ${ }^{50-55}$ From a population health perspective, $\mathrm{PN}$ may still be underutilized, ${ }^{56}$ despite its association with a lower risk of long-term renal dysfunction ${ }^{57-59}$ compared to radical nephrectomy (RN), while providing similar oncologic outcomes. ${ }^{60,61}$ Tumour enucleation, regardless of the approach for exophytic lesions, seems to offer equivalent outcomes to $\mathrm{PN}$ when a negative surgical margin is established. ${ }^{62} \mathrm{PN}$ may also be associated with a lower risk of long-term cardiovascular events. ${ }^{63-65}$ Laparoscopic or robotic-assisted laparoscopic PN can result in comparable surgical and oncologic outcomes in the hands experienced surgeons. ${ }^{66,67}$ While the impact of a positive surgical margin on subsequent disease outcome has not definitively been shown to adversely affect survival outcomes, a negative surgical margin is always the goal of any nephron-sparing procedure. It is also a required metric of surgical quality of care. ${ }^{68,69}$

A recent European Organization for Research and Treatment of Cancer (EORTC) trial evaluated overall survival and time to cancer progression in 541 patients randomized to PN or RN for T1-T2N0 lesions suspicious for $\mathrm{RCC},{ }^{70}$ but also supported noninferiority of PN. The results indicated an overall survival advantage for patients undergoing $\mathrm{RN}$, contrary to previously reported retrospective data. When pathologically eligible patients were evaluated, the differences in survival were less pronounced, and the $\mathrm{RN}$ was no longer statistically superior. PN did demonstrate maintenance of renal function with a slightly higher risk of perioperative complications. This study has somewhat tempered enthusiasm for PN in the elective setting, despite the overwhelming evidence for $\mathrm{PN}$ in medical renal disease. ${ }^{71}$ However, numerous shortcomings of this study (such as premature study closure, baseline and cross-over related patient comorbidity imbalances, low statistical power, variable surgical technique and parenchymal sparing) have rendered its interpretation problematic. A further prospective investigation should be able to shed light on the role of PN versus $\mathrm{RN}$ in this and other populations.

The use of image-guided ablative technologies in the management of T1a RCC is widely accessible in Canadian institutions. Despite the lack of long-term recurrence and survival data, radiofrequency ablation (RFA) or cryotherapy performed either percutaneously under image guidance or laparoscopically, is a viable management option in patients with tumours less than $3 \mathrm{~cm}$ in diameter, with infrequent complications; 
they do, however, have a slightly higher risk of local recurrence compared to $\mathrm{PN}^{72-74}$ Currently, patients considered for ablative approaches are those with severe medical comorbidities precluding surgical extirpation, or in patients with multiple bilateral lesions, possibly due to underlying genetic predispositions (Birt-Hogg-Dubé syndrome, Von Hippel-Lindau disease). Several technologies and approaches are differentially used with success, although long-term oncologic outcomes are not yet available. ${ }^{75,76}$ Pre-treatment or concomitant biopsy in these cases is recommended. ${ }^{77}$

\section{Active surveillance}

\begin{abstract}
- The long-term safety of initial active surveillance with delayed treatment for progression is not yet established. However, it is an alternative for managing SRMs that are asymptomatic and characteristic of RCC on imaging in the elderly and/or infirm. It is not yet recommended for the young and fit.

- Follow-up must include serial imaging.
\end{abstract}

Active surveillance for SRM lesions has gained widespread acceptance owing to strong clinical research demonstrating safety in select patient populations. ${ }^{78,79}$ Canadian experience with active surveillance has been documented, and has been associated with low risk of metastasis. ${ }^{80}$ This group also demonstrated a growth rate of $0.13 \mathrm{~cm} /$ year, which did

\section{Stage T1bNOMO \\ - PN (open/laparoscopic/robotic) in cases where technically feasible \\ - Laparoscopic RN should be offered if a PN is not feasible \\ - Open RN if laparoscopic surgery not possible.}

not correlate with histology in a subgroup of patients with histologically confirmed RCC. Lesions $<4 \mathrm{~cm}$ with elevated growth rates have increased the risk of local or systemic progression and should be considered for definitive extirpation or ablation. ${ }^{79,81}$ Data suggest that lesions greater than $2.45 \mathrm{~cm}$ in diameter are more likely to have accelerated growth rates. ${ }^{82}$ An emerging and safe trend may be routine biopsy in patients with SRM to confirm malignant histology. Active surveillance is a viable option after histological confirmation of RCC and may help to further risk-stratify patients for management or tailoring of follow-up imaging. ${ }^{33,84}$ Despite the low risk of metastasis, the documented potential of systemic $(1.1 \%)$ or local progression (12\%) merits consideration when counselling patients. ${ }^{80,85}$ Management of SRM in elderly patients has also been investigated in several series, and active surveillance has been associated with a greater overall survival compared to active surgical or ablative therapy. ${ }^{86,87}$ The selection of active surveillance as a validated treatment option is supported by the literature. It should be considered for patients with significant comorbid medical disease and for elderly patients.
The use of PN for T1bN0M0 cases was supported initially for patients with solitary kidneys or with renal functionendangering medical comorbidity. ${ }^{88}$ However, with the technical advancement in the field, supported by clinical research and the rising global impact of medical renal disease, ${ }^{71} \mathrm{PN}$ has been applied in patients with normal contralateral kidneys. ${ }^{89}$

Although PN is safe, oncologically equivalent to $\mathrm{RN}$, and offers an effective means to prevent surgically induced renal dysfunction, ${ }^{90-92}$ randomized data have modified enthusiasm for $\mathrm{PN}$ for $\mathrm{T} 1 \mathrm{~b}$ lesions to a greater degree than lesions under $4 \mathrm{~cm}^{70,93}$ Despite the aforementioned study limitations, the positive comparative overall survival of $\mathrm{RN}$ compared to $\mathrm{PN}$ in the T1b population in an intent-to-treat analysis is noteworthy, and may raise uncertainty about the efforts to expand PN for patients with larger and more complex tumours in the elective setting.

Nevertheless, the expertise required to perform PN in larger tumours is growing in many tertiary care institutions, ${ }^{94}$ but the general uptake is still modest. ${ }^{95}$ Recent studies have shown similar outcomes for open PN and minimally invasive $\mathrm{PN} .{ }^{96}$ Minimally invasive approaches to $\mathrm{PN}$ for tumours between 4 and $7 \mathrm{~cm}$ present a further surgical challenge, but are certainly feasible and effective in experienced hands. ${ }^{97-99}$ Although many patients with positive surgical margins do not experience local relapse, there may be a greater importance in attaining a negative surgical margins in larger lesions, related to greater risks of higher grade tumours. Several important technical advances have enabled laparoscopic surgeons to maintain acceptable ischemia times..$^{50,100,101}$

If a PN is not feasible, a laparoscopic $\mathrm{RN}$ is the surgery of choice and is preferred to open $\mathrm{RN}$, secondary to improvements in postoperative recovery, pain, and return to normal activity. ${ }^{102,103}$ When LRN is not feasible, open PN is preferred. Ablative modalities are not recommended for these tumours due to the high rate of incomplete ablation in lesions greater than $4 \mathrm{~cm} .{ }^{104-106}$

\section{Stage T2NOMO \\ - RN - open/laparoscopic/robotic \\ - PN - open/laparoscopic/robotic}

Patients with tumours larger than $7 \mathrm{~cm}$ have traditionally been managed with laparoscopic or open $\mathrm{RN},{ }^{107,108}$ although open $\mathrm{RN}$ remains an option for patients not suitable for laparoscopic RN. Both minimally invasive and open approaches have been associated with equivalent cancer-specific outcomes, ${ }^{109,110}$ with a potential for fewer perioperative complications. ${ }^{111}$ Robotic RN in selected cases is feasible. ${ }^{54,108,112,113}$ The role of extended PN for tumours greater than $7 \mathrm{~cm}$ is controversial, and the consideration of such highly selected cases should be limited to experienced surgeons. ${ }^{114-116}$ 
Stage T3

- RN - open, laparoscopic or robotic assisted

o Resection of vascular thrombus when applicable (usually open)

o Resection of all gross disease including hilar or retroperitoneal extension

- PN may be attempted in highly selected cases by experienced surgeons.

Patients with tumours greater than $7 \mathrm{~cm}$ should raise suspicion of involvement of peri-renal tissues, such as Gerota's fascia or renal sinus fat. ${ }^{117}$ Current TNM staging reflects the higher rate of disease recurrence with peri-renal tissue involvement. ${ }^{118-122}$ Other series have not supported universal upstaging for all locally advanced tumours, and suggest variable survival differences based on sites of regional tumour extension. ${ }^{123,124}$ In many cases, T3 disease can only be pathologically determined based on pathologic evidence of muscular venous branch invasion, which has been associated with an adverse prognostic impact. ${ }^{125-127}$ Some investigators use MRI to help to preoperatively identify muscular venous branch invasion. ${ }^{128}$ Technical considerations regarding the optimal surgical approach may be modified based on disease stage, the presence or level of vascular tumour thrombus, and the feasibility of negative margins. ${ }^{129,130}$ Open or laparoscopic RN is the management option of choice, with most tumour thrombi necessitating an open approach. PN (open or laparoscopic) is feasible in highly selected patients in the hands of experienced renal surgeons. ${ }^{51}$ Ipsilateral involvement of the adrenal gland from upper pole tumours portends a more guarded prognosis, with recent upstaging to T4 on the most recent TNM classification. ${ }^{131}$

\section{Management of the IVC and renal vein thrombus}

\footnotetext{
- In the presence or absence of distant metastases, tumour thrombus should be resected if technically feasible in appropriately selected patients

- It is recommended that these operations be performed in a centre with experience and with an availability of a multidisciplinary team as these complex procedures have significant risk of morbidity and mortality.
}

About $4 \%$ to $10 \%$ of all RCCs involve the IVC, with a smaller subset extending to the right atrium. RCC with intravascular disease at any level is associated with higher-grade disease and a worse prognosis. ${ }^{127,132}$ Distant lymph node or metastatic disease is more common in this population. ${ }^{133}$ Renal vein involvement may be visualized with CT, MRI or Doppler ultrasound. ${ }^{134,135}$ Nephrectomy and tumour thrombectomy in the absence of metastasis may provide durable disease response with acceptable morbidity. ${ }^{136}$ Tumour thrombectomy with cytoreductive nephrectomy in the metastatic setting should be considered for all patients secondary to the poor outcome associated with untreated intravascular disease.
Statistical prediction tools and patient scoring criteria may help better select patients who may derive maximum benefit from these procedures. ${ }^{137,138}$ Expertise and advanced surgical planning are necessary, and referral to high volume centres is recommended due to the possibility of requiring vascular reconstruction, or access to cardiothoracic and hepatobilliary surgical support. ${ }^{139-141}$

Appropriately selected cases can be managed via minimally invasive approaches using innovative approaches to manage vascular thrombi. ${ }^{142-147}$

The advent of vascular endothelial growth factor targeted therapies has challenged the role of cytoreductive nephrectomy, but less so in patients with intravascular thrombus. ${ }^{148-150}$ The survival benefits of multimodality approaches are in need of prospective evaluation, but current data suggest a primary role for surgical resection of tumour vascular thrombi in patients with metastatic disease.

\section{Special considerations}

\section{Role of adrenalectomy}

\footnotetext{
The ipsilateral adrenal gland should be preserved at the time of the nephrectomy provided it appears normal on imaging and there is no sign of direct tumour invasion.
}

The incidence of ipsilateral adrenal involvement is $1.9 \%$ to $7.5 \% .{ }^{151}$ Current evidence does not support adrenalectomy in all patients with localized RCC. Disease-specific survival (5- and 10-year) and recurrence-free survival are equivalent regardless of whether ipsilateral adrenalectomy is performed in cases in which the gland does not appear to be involved. ${ }^{152} \mathrm{CT}$ imaging has been shown to have as high as $99.4 \%$ specificity and a $99.4 \%$ negative predictive value. ${ }^{153}$ Metastatic disease to the ipsilateral adrenal gland as the only site of metastatic spread is low at $0.7 \%$ to $2 \% .^{154}$ Ipsilateral adrenalectomy may be performed for patients with abnormal imaging, advanced stage (T3-4), or upper pole tumours greater than $7 \mathrm{~cm}$.

\section{Role of lymphadenectomy}

\footnotetext{
- Routine lymphadenectomy at the time of RN or PN is not routinely recommended in patients with clinical NO disease.

- Lymphadenectomy is recommended in patients with clinical $\mathrm{N} 1 \mathrm{M} 0$ disease.

- Lymphadenectomy may be performed for diagnostic purposes in patients with clinical N1M1 disease.
}

Regional lymph-node dissection combined with $\mathrm{RN}$ has a minimal effect in operative time, morbidity or mortality in an EORTC trial of 772 clinically node-negative patients ran- 
domized to regional lymphadenectomy or not at the time of nephrectomy. ${ }^{155}$

There is no demonstrated survival benefit to resection of clinically negative regional nodes. In patients with clinically enlarged nodes and no evidence of distant metastatic disease, single-institution, retrospective series indicate that resection of these nodes may result in a survival benefit. ${ }^{84,156,157}$

\section{Role of neoadjuvant therapy in kidney cancer}

Currently there is no role for neoadjuvant therapy outside of a clinical trial.

Neoadjuvant therapy is defined as pre-surgical medical treatment for patients undergoing definitive surgical resection of their kidney cancer with curative intent (i.e., non-metastatic disease). In theory the goals of neoadjuvant therapy for locally advanced disease are to reduce the risk of recurrence, reduce the size of tumours to make unresectable tumours resectable, reduce the rate of positive surgical margins, make $\mathrm{PN}$ more feasible, or to simplify the resection of venous thrombus.

Most of the data on the impact of neoadjuvant therapy on the primary tumour are extrapolated from studies on metastatic RCC. ${ }^{158}$ Sorafenib has been evaluated in the neoadjuvant or pre-surgical setting in patients with stage II or higher RCC awaiting nephrectomy. In this non-randomized study of 30 patients, a reduction in size was seen in $77 \%$ of patients with a median decrease in size of $9.6 \% .{ }^{159}$ Other similar studies have shown a small decrease in size with neoadjuvant therapy. ${ }^{160-162}$

A potential benefit of neoadjuvant therapy is to make an unresectable lesion resectable; however, surgical resectablity is subjective and poorly defined. ${ }^{163,164}$ In the modern era, fewer than $1 \%$ of cases are unresectable and, given that striking responses in the primary lesion are rare, this is unlikely to have a significant role. ${ }^{158}$

Silberstein and colleagues examined the use of neoadjuvant sunitinib in 12 patients prior to $\mathrm{PN}$. After tyrosine-kinase inhibitor (TKI) therapy, the average tumour size decreased from 7.1 to $5.6 \mathrm{~cm}$. All attempted PNs were successful with negative margins. ${ }^{165}$ Other studies demonstrate that $\mathrm{PN}$ is feasible after TKI therapy, but they do not provide efficacy data to support the use of systemic therapy prior to PN. ${ }^{158}$

Neoadjuvant therapy has been studied in patients with IVC thrombus to assess if it can downsize the thrombus and improve surgical resectability. A retrospective study was done with 25 patients with level II or higher thrombus who were treated with targeted molecular therapies. Thrombus height increased in 7 patients, decreased in 11 patients and remained unchanged in 7 patients. ${ }^{166}$ At this time the data do not support the use of neoadjuvant therapy for tumour thrombus and further studies are needed.
Most studies have shown that preoperative therapy is safe, although a mild increase in wound complications has been observed. There are potential advantages to neoadjuvant therapy in locally advanced disease, however, currently the data are limited and further investigation is needed.

\section{Role of pre-surgical therapy in advanced kidney cancer}

- Currently there is no role for pre-surgical therapy outside of a clinical trial.

Pre-surgical therapy is defined as preoperative medical therapy in patients with locally advanced or metastatic RCC prior to cytoreductive RN. There are several potential advantages. Pre-surgical therapy may alleviate symptoms related to RCC before surgery and may downsize the primary tumour to facilitate subsequent resection. Pre-surgical therapy will help to identify patients with refractory disease who are unlikely to benefit from cytoreduction and therefore may avoid surgery.

Pre-surgical therapy to downsize primary tumours was assessed in a prospective trial using sunitinib for 12 to 18 weeks prior to nephrectomy. The response rate was $14 \%$ and the overall effect on the size of the primary tumour was modest. ${ }^{167}$ The pre-surgical therapy currently available does not have a significant role in downsizing the primary tumour.

The utility of pre-surgical therapy to identify patients with refractory disease who may be spared a nephrectomy and the risks associated with surgery remains undemonstrated. ${ }^{158,168}$ Evidence to help support the use of pre-surgical therapy was demonstrated in a phase II pre-surgical study that examined the role of bevacizumab. The authors found a median progression-free survival of 11 months and a median overall survival of 25.4 months. ${ }^{161}$ The authors noted this was comparable to post-surgical treatment.

Postoperative complication rates tend not to increase after pre-surgical medical therapy. One study compared complications within 12 months in patients who received pre-surgical systemic therapy against those who had a cytoreductive nephrectomy initially. Pre-surgical treatment was not associated with an increase of severe surgical complications (Clavien 3 or more) on multivariate analysis. However, an increase in wound complications was observed. ${ }^{169}$ The role of pre-surgical therapy requires further investigation. There are currently a number of phase II trials ongoing. Two phase III trials are assessing the impact of sunitinib prior to cytoreductive nephrectomy, the EORTC (SURTIME) and European CARMINA trial. ${ }^{170}$ Results of these trials are expected within the next 3 to 5 years. 


\section{Role of adjuvant therapy in kidney cancer}

Currently there is no role for adjuvant therapy outside of a clinical trial.

Adjuvant therapy is defined as postoperative medical therapy after surgical resection with definitive curative intent. The aim of adjuvant therapy is to decrease the risk of cancer recurrence in patients with features indicative of intermediate- or high-risk for recurrence. In patients with kidney cancer, high-risk features for recurrence include high grade (Fuhrman's Grade 3 or 4), high T-stage (>T2b), unfavourable histology, and nodal involvement.

Currently the standard of care after resection of intermediate or high-risk kidney cancer is watchful waiting. Radiotherapy, cytotoxic chemotherapy, immunotherapy, and antiangiogenic therapies have been studied in the adjuvant setting. ${ }^{158}$ Multiple studies have demonstrated no benefit to adjuvant radiation. ${ }^{171,172}$

Immunotherapy has been studied in the adjuvant setting without evidence of benefit. ${ }^{173-176} \mathrm{~A}$ randomized controlled study used interferon as an adjuvant treatment in 247 patients with stage II or III RCC did not demonstrate a significant improvement in overall survival $(p=0.86)$ and event-free survival $(p=0.11) .{ }^{173}$ Another phase III randomized controlled prospective study used II-2 in the adjuvant setting and did not show a benefit. ${ }^{176}$ The only study to demonstrate an advantage with adjuvant treatment is one that used an autologous RCC vaccine. This study demonstrated an improved progression-free survival of 77.4 versus $67.8 \%$ $(p=0.039)$ at 5 years. ${ }^{177}$ However, the study had significant methodological flaws and other vaccine studies have not shown a benefit. ${ }^{158}$

We are still awaiting the results from several trials examining adjuvant therapy. The REC.2 ASSURE trial, comparing postoperative sunitinib versus sorafenib versus placebo in patients at high risk for recurrence, completed accrual in 2012 and the results are expected in 2015. The S-TRAC trial is a phase III trial where patients with high-risk RCC are randomized to 1 year of sunitinib or placebo. The results are expected in 2017. The SORCE trial is a phase III randomized double-blind study comparing sorafenib to placebo in patients with resected intermediate- to high-risk RCC. The PROTECT trial is a randomized, double-blind, placebo-controlled phase III trial. The trial evaluates the efficacy and safety of pazopanib versus placebo as adjuvant therapy for patients with localized or locally advanced RCC following nephrectomy. It is currently in progress and the estimated completion date is 2017 .

\section{T4NOMO (Local tumour extension to adjacent organs without metastatic disease)}

- RN with resection of adjacent organs if feasible.

The only treatment modality with potential to achieve cure with T4 disease is surgical resection. ${ }^{178}$ The goal of surgery is to remove all known disease, with possible concomitant resection of involved organs, such as the adrenal gland, liver, pancreas, diaphragm, and bowel. It is recommended that these cases are performed at high volume centres with a multidisciplinary surgical team. Even with complete resection, 5-year survival is poor and the oncological benefits of surgery should be carefully considered in the context of surgical morbidity. ${ }^{124,179-181}$ A significant proportion of these patients will have occult lymph node metastases, and regional lymphadenectomy should therefore be considered for adequate pathologic staging. ${ }^{178,182,183}$ Pre-surgical systemic treatments are experimental and phase III trials evaluating adjuvant systemic agents are ongoing.

\section{TanyN+MO (Radiographic and clinical evidence of lymph node enlarge- ment)}

- RN and regional lymphadenectomy

There are no randomized trials assessing the effect of lymphadenectomy for patients with RCC and clinical lymphadenopathy. However, a subset of patients with regional lymph node metastases will be cured, or experience prolonged survival following surgery. ${ }^{141}$ Enlargement of regional lymph nodes in RCC is often not due to metastases. ${ }^{155,184}$ Therefore, lymphadenectomy provides important prognostic information for these patients.

\section{T-any $\mathrm{N}$-any $\mathrm{M}+$ (Distant metastases at the time of renal tumour diagnosis)}

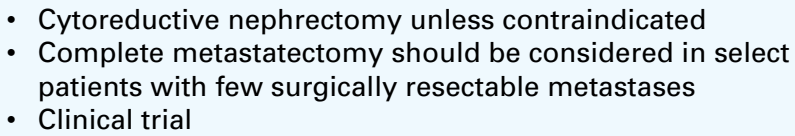

- Cytoreductive nephrectomy unless contraindicated

- Complete metastatectomy should be considered in select patients with few surgically resectable metastases

- Clinical trial

There are no randomized trials assessing the effect of complete surgical resection versus cytoreductive nephrectomy followed by systemic therapy versus systemic therapy without nephrectomy. Since systemic therapy is not curative, complete surgical resection can be considered in selected patients. In published cohorts, a subset of patients will be cured or experience prolonged survival following complete resection of synchronous metastases. ${ }^{185-191}$ This strategy can sometimes spare patients of prolonged periods of time from 
the toxicity of systemic therapy. Favourable prognostic factors include a limited number of metastatic sites, a limited number of metastases, and location of metastases (adrenal, pancreas, and lung). ${ }^{192}$ The potential benefits of complete resection of synchronous metastases should be balanced with the known surgical risks. ${ }^{192}$ Metastatectomy should also be considered for palliation in symptomatic patients. ${ }^{193}$

\section{Cytoreductive nephrectomy (Role of nephrectomy in patients with metastatic R(C)}

\section{- Cytoreductive nephrectomy is recommended in patients presenting with metastatic RCC unless contraindications are present. \\ - Clinical trial}

Meta-analysis of 2 randomized controlled trials reveals that nephrectomy combined with immunotherapy prolongs survival compared to immunotherapy alone for patients who present with metastatic RCC (median survival 13.6 months vs. 7.8 months). ${ }^{194}$ The greatest benefit of nephrectomy is experienced in healthy patients (ECOG [Eastern Cooperative Oncology Group] 0 or 1) with a low volume of metastatic disease and absence of critical brain metastases. Nephrectomy may provide palliative benefits in patients with pain and hematuria and a small percentage of patients will experience spontaneous regression of metastases following nephrectomy. ${ }^{195,196}$ There are no completed randomized trials on the use of nephrectomy in the targeted therapy era. However, the ongoing use of cytoreductive nephrectomy is supported by the fact that most patients ( $>90 \%$ ) enrolled in clinical trials for molecular targeted treatment had a nephrectomy, ${ }^{197,198}$ and observational studies of contemporary patients reveal an association between nephrectomy and prolonged survival. ${ }^{199}$

Several studies have helped identify patients least likely to benefit from cytoreductive nephrectomy. ${ }^{200-202}$ Cytoreductive nephrectomy exclusion factors can be categorized into patient, metastatic, and histologic factors. Patient factors include poor performance status (ECOG $>1$ ) and age greater than 75 . Metastatic factors include $>25 \%$ of total tumour volume in metastatic sites, central nervous system metastases, liver metastases, symptomatic metastases and distant lymph node metastases. Histologic factors include non-clear-cell histology and sarcomatoid features. Recent studies have also suggested laboratory studies, such as serum albumin and lactate dehydrogenase, may help predict prognosis and thus help determine which patients would be most appropriate for cytoreductive nephrectomy. ${ }^{203,204}$

\section{The role of metastatectomy in patients with distant recurrence}

- Resection of metastatic tumours should be considered for well selected patients

There are no randomized trials comparing metastatectomy to systemic treatments. However, among patients who develop metachronous metastases following nephrectomy, about one-third are eligible for metastatectomy ${ }^{205}$ and several large cohorts report long-term survival for a subset of patients after complete resection of metastases. ${ }^{185-192}$ Isolated metastases to the lung, ${ }^{206-211}$ bone, ${ }^{193,212-215}$ pancreas, ${ }^{216}$ and adrenal glands ${ }^{217,218}$ have the most favourable prognosis. Based on available observational data, patients most likely to benefit from metastatectomy are those diagnosed with metastases over 2 years following nephrectomy, those with isolated metastases, and those with favourable metastatic locations. ${ }^{192}$ In all scenarios, the potential benefits of surgery must carefully weighed against the inherent operative risks. ${ }^{192}$

\section{Follow-up of RCC}

\section{Active surveillance}

- Optimal follow-up regimen is unclear.

- Regular surveillance of the primary tumour is recommended, initially at 3 to 6 months then followed yearly (CT, ultrasound MRI).

- Chest x-ray should be performed yearly to screen for pulmonary metastases.

- Duration of follow-up should be tailored to individual patient risk factors.

Active surveillance in SRMs $(<3.0-4.0 \mathrm{~cm})$ is an option for patients with significant comorbidities or reduced life expectancy. In this population, about $20 \%$ to $30 \%$ of SRMs are benign, while $70 \%$ to $80 \%$ are low-grade, and renal biopsy may help to identify benign tumours from malignant ones, as well as to differentiate low-grade from high-grade tumours. ${ }^{34,219,220}$ These patients should be followed with regular imaging to assess for changes in tumour size. Patients must be warned of a risk of $<2 \%$ of metastases, as shown in multiple prospective studies. ${ }^{34,82,220}$ The optimal follow-up protocol is not known, but regular surveillance is recommended to ascertain growth and metastases. ${ }^{154}$ Abdominal imaging (CT, ultrasound, MRI) should be obtained at 3 to 6 months to ascertain a growth rate, followed by yearly imaging. ${ }^{34,82,220}$ As well, chest $x$-rays should be performed yearly to screen for pulmonary metastases..$^{34,82,220}$ Duration of follow-up should be tailored to individual patient risk factors and life expectancy. 


\section{Needle ablation treatments}

- Optimal follow-up regimen is unclear.

- Regular surveillance of the primary tumour is recommended, initially at 3 to 6 months followed every 6 months to 1 year (CT, ultrasound, MRI).

- Chest x-ray should be performed yearly to screen for pulmonary metastases.

- Duration of follow-up should be tailored to individual patient risk factors.

Ablative therapies to treat SRMs are an option for patients with SRMs that are $<3.0$ to $4.0 \mathrm{~cm}$ or who do not wish to undergo surgery or who have comorbidities that make them unsuitable for surgery. ${ }^{221-223}$ Most data for use of ablative therapy in renal cancer are derived from either cryotherapy or RFA. These treatments should be performed in centres where the interventional radiologists have significant experience. As well, discussion between the urologist and radiologist at a multidisciplinary conference is ideal. Biopsy at the time of ablative therapy should be performed to aid in future management and follow-up in these patients. A post-treatment biopsy should be performed upon confirmation of enhancing areas seen in follow-up imaging studies.
Re-treatment may be required in $2 \%$ to $10 \%$ of patients and progression may occur in up to $13 \%$ of patients. ${ }^{223}$ Close follow-up is thus required and consideration of surgical intervention should be considered if progression occurs. Abdominal imaging (CT, ultrasound, MRI) at first at 3 to 6 months followed by imaging every 6 to 12 months should be performed to ascertain tumour growth and progression. ${ }^{221-223}$ As well, yearly chest X-rays should be performed to screen for pulmonary metastases. ${ }^{221-223}$ The duration of follow-up should be tailored to individual patient risk factors and life expectancy.

\section{Post-surgical resection}

A follow-up regimen should be established based on the risk of recurrence. Tumours with higher stage and higher Fuhrman grade have a higher and earlier risk of recurrence. Several follow-up guidelines are available. The recommended Canadian Urological Association guidelines for the follow-up of post-surgical resection have been adopted (Fig. 1). ${ }^{224}$

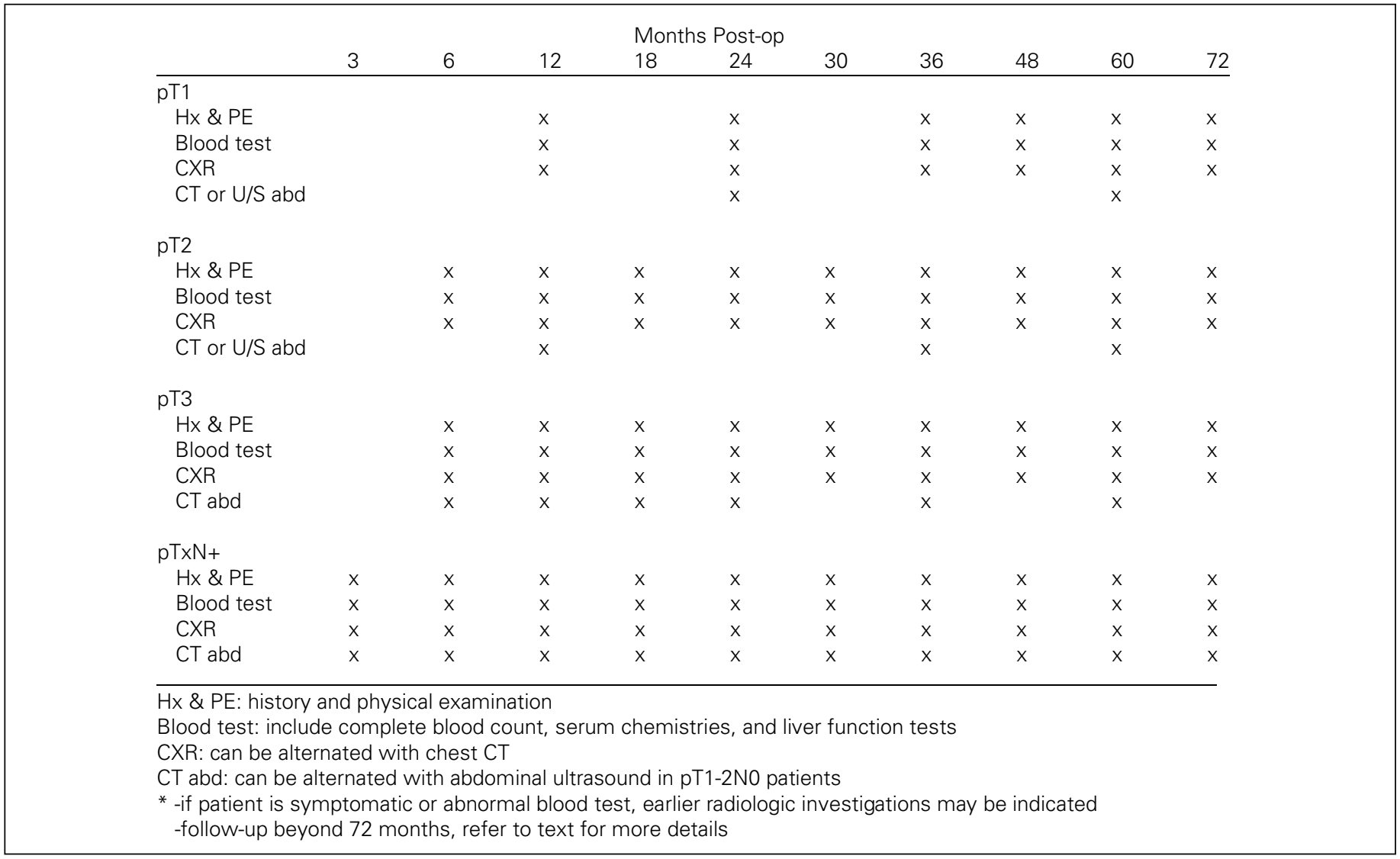

Fig. 1. Canadian Urological Association (CUA) recommendations for the follow up of patients after radical or partial nephrectomy. Reprinted from reference 15 with permission of the CUA. 


\section{Low risk patients (pTl, NO, Nx)}

Post-surgical follow-up of patients should be tailored to individual patient risk factors. In low-risk patients, a baseline postoperative abdominal scan (CT, MRI or ultrasound) should be performed within 24 months following surgery. In patients undergoing $\mathrm{PN}$, a CT or MRI may provide better imaging to rule out recurrence in the surgical field. Optimal frequency of repeat imaging in low-risk patients is uncertain, but may be discontinued after 3 to 5 years of normal imaging since most recurrences occur in this time period. ${ }^{205}$ All patients with low-risk disease should receive a yearly chest $\mathrm{x}$-ray to screen for pulmonary metastases for the first 3 to 6 years.

\section{Moderate to high-risk patients (pT2-4NO Nx or any stage $\mathrm{N}+$ )}

In moderate- to high-risk patients, the frequency of abdominal imaging is increased. Patients should undergo a baseline postoperative abdominal scan (CT or MRI) within 6 months following surgery with frequency of repeat imaging based on individual risk factors. Follow-up should occur for at least 5 years. ${ }^{205}$ Moreover, patients should have a chest $\mathrm{CT}$ or chest $\mathrm{x}$-ray yearly for 5 years.

Competing interests: Dr. Rendon is a member of the Advisory Board and the Speakers bureau for Amgen, Astellas, Ferring and Janssen. Dr. Kapoor is a member of the Speakers bureau for, and has received grants and honoraria from, Pfizer Oncology, GSK Oncology, Novartis Oncology and Amgen. He has also participated in clinical trials within the past 2 years with NCIC, Pfizer, GSK, Novartis and Amgen. Dr. Black is a member of the ad hoc Advisory Boards for Amgen, Janssen, Ferring and Astellas. He has received an industry-partnered grant (2012) from GenoneDx. Dr. So is a member of the Speakers' Bureau for Amgen, Astellas, and Janssen. Dr. Breau, Dr. Leveridge and Dr. Feifer declare no competing financial or personal interests.

This paper has been peer-reviewed.

\section{References}

1. Advisory CCSs, Statistics CoC. Canadian Cancer Statistics 2013. Canadian Cancer Society. Toronto, ON; 2013.

2. Jemal A, Simard EP, Dorell C, et al. Annual Report to the Nation on the Status of Cancer, 1975-2009, featuring the burden and trends in human papillomavirus (HPV)-associated cancers and HPV vaccination coverage levels. J Natl Cancer Inst 2013;105:175-201.

3. Hollingsworth JM, Miller DC, Daignault $S$, et al. Rising incidence of small renal masses: a need to reassess treatment effect. J Natl Cancer Inst 2006;98:1331-4.

4. Volpe A, Panzarella T, Rendon RA, et al. The natural history of incidentally detected small renal masses. Cancer 2004;100:738-45.

5. Calle EE, Kaaks R. Overweight, obesity and cancer: Epidemiological evidence and proposed mechanisms. Nat Rev Cancer 2004;4:579-91.

6. Hunt JD, van der Hel $\mathrm{OL}, \mathrm{McMillan} \mathrm{GP}$, et al. Renal cell carcinoma in relation to cigarette smoking: Meta-analysis of 24 studies. Int J Cancer 2005;114:101-8.

7. Macleod LC, Hotaling JM, Wright JL, et al. Risk factors for renal cell carcinoma in the vitamin and lifestyle (VITAL) study. J Urol 2013;190:1657-61. http://dx.doi.org/10.1016/i.juro.2013.04.130.

8. Motzer RJ, Bacik J, Schwartz LH, et al. Prognostic factors for survival in previously treated patients with metastatic renal cell carcinoma. J Clin Oncol 2004;22:454-63.
9. Heng DY, Xie W, Regan MM, et al. Prognostic factors for overall survival in patients with metastatic renal cell carcinoma treated with vascular endothelial growth factor-targeted agents: Results from a large, multicenter study. J Clin Oncol 2009;27:5794-9.

10. Catalano C, Fraioli F, Laghi A, et al. High-resolution multidetector $C T$ in the preoperative evaluation of patients with renal cell carcinoma. AJR Am J Roentgenol 2003;180:1271-7.

11. Yoon J, Herts BR. Staging renal cell carcinoma with helical CT: The revised 1997 AJCC and UICC TNM criteria. Crit Rev Comput Tomogr 2003;44:229-49. http://dx.doi.org/10.3109/bctg.44.4.229.249

12. Kang SK, Chandarana H. Contemporary imaging of the renal mass. Urol Clin North Am 2012;39:161-70.

13. Guo HF, Song Y, Na YQ. Value of abdominal ultrasound scan, $\mathrm{CT}$ and MRI for diagnosing inferior vena cava tumour thrombus in renal cell carcinoma. Chin Med J (Engl) 2009;122:2299-302.

14. Khan AR, Anwar K, Fatima N, et al. Comparison of CT scan and colour flow Doppler ultrasound in detecting venous tumour thrombous in renal cell carcinoma. J Ayub Med Coll Abbottabad 2008;20:47-50.

15. Ueno D, Yao M, Tateishi U, et al. Early assessment by FDG-PET/CT of patients with advanced renal cell carcinoma treated with tyrosine kinase inhibitors is predictive of disease course. BMC Cancer 2012;12:162.

16. Kumar R, Shandal V, Shamim SA, et al. Role of FDG PET-CT in recurrent renal cell carcinoma. Nucl Med Commun 2010;31:844-50.

17. Nakatani $K$, Nakamoto Y, Saga T, et al. The potential clinical value of FDG-PET for recurrent renal cell carcinoma. Eur J Radiol 2011;79:29-35.

18. Israel GM, Bosniak MA. An update of the Bosniak renal cyst classification system. Urology 2005;66:484-8.

19. Israel GM, Hindman N, Bosniak MA. Evaluation of cystic renal masses: comparison of CT and MR imaging by using the Bosniak classification system. Radiology 2004;231:365-71.

20. Graumann 0, Osther SS, Karstoft J, et al. Evaluation of Bosniak category IIF complex renal cysts. Insights Imaging 2013;4:471-80. http://dx.doi.org/10.1007/s13244-013-0251-y

21. Israel GM, Bosniak MA. Follow-up CT of moderately complex cystic lesions of the kidney (Bosniak category IIF). AIR Am J Roentgenol 2003;181:627-33.

22. El-Mokadem I, Budak M, Pillai $S$, et al. Progression, interobserver agreement, and malignancy rate in complex renal cysts (>/=Bosniak category IIF). Urol Oncol 2014;32:24.e21-7.

23. Warren KS, McFarlane J. The Bosniak classification of renal cystic masses. BJU Int 2005;95:939-42.

24. Edge SB, Byrd DR, Compton CC, Fritz AG, Greene FL, Trotti A, editors. AJCC cancer staging manual (7th ed). New York, NY: Springer; 2010.

25. Violette P, Abourbih S, Szymanski KM, et al. Solitary solid renal mass: Can we predict malignancy? BJU Int 2012;110:E548-52. http://dx.doi.org/10.1111/j.1464-410X.2012.11245.x

26. Soga N, Nishikawa K, Takaki H, et al. Low incidence of benign lesions in resected suspicious renal masses greater than $2 \mathrm{~cm}$ : Single-center experience from Japan. Int J Urol 2012;19:729-34.

27. Rendon RA, Ross JM, Kirklaand $S$, et al. A classification tree for the prediction of benign disease in the management of renal masses: Aiding the clinician's thought process. J Urol 2011;185:e280-1. http:// dx.doi.org/10.1016/i.juro.2011.02.1664

28. Organ $M$, Jewett $M$, Almatar $A$, et al. External validation and creation of a new classification tree for the prediction of benign versus malignant disease in patients with sall renal masses. J Urol 2013;189:e492. http://dx.doi.org/10.1016/i.juro.2013.02.2555

29. Lane BR, Babineau D, Kattan MW, et al. A preoperative prognostic nomogram for solid enhancing renal tumours $7 \mathrm{~cm}$ or less amenable to partial nephrectomy. J Urol 2007;178:429-34.

30. Kutikov A, Smaldone MC, Egleston BL, et al. Anatomic features of enhancing renal masses predict malignant and high-grade pathology: A preoperative nomogram using the RENAL Nephrometry score. Eur Urol 2011;60:241-8

31. Wang HK, Zhu Y, Yao XD, et al. External validation of a nomogram using RENAL nephrometry score to predict high grade renal cell carcinoma. J Urol 2012;187:1555-60.

32. Mullins JK, Kaouk JH, Bhayani $S$, et al. Tumour complexity predicts malignant disease for small renal masses. J Urol 2012;188:2072-6.

33. Lebret T, Poulain JE, Molinie V, et al. Percutaneous core biopsy for renal masses: Indications, accuracy and results. J Urol 2007;178:1184-8; discussion 1188.

34. Leveridge MJ, Finelli A, Kachura JR, et al. Outcomes of small renal mass needle core biopsy, nondiagnostic percutaneous biopsy, and the role of repeat biopsy. Eur Urol 2011;60:578-84. http://dx.doi. org/10.1016/i.eururo.2011.06.021

35. Maturen KE, Nghiem HV, Caoili EM, et al. Renal mass core biopsy: Accuracy and impact on clinical management. AJR Am J Roentgenol 2007; 188:563-70.

36. Menogue SR, $O^{\prime} B$ rien BA, Brown AL, et al. Percutaneous core biopsy of small renal mass lesions: a diagnostic tool to better stratify patients for surgical intervention. BJU Int 2013;111:E146-51.

37. Richter F, Kasabian NG, Irwin RJ Jr, et al. Accuracy of diagnosis by guided biopsy of renal mass lesions classified indeterminate by imaging studies. Urology 2000;55:348-52.

38. Schmidbauer J, Remzi M, Memarsadeghi $M$, et al. Diagnostic accuracy of computed tomography-guided percutaneous biopsy of renal masses. Eur Urol 2008;53:1003-11.

39. Shannon BA, Cohen RJ, de Bruto $\mathrm{H}$, et al. The value of preoperative needle core biopsy for diagnosing benign lesions among small, incidentally detected renal masses. J Urol 2008;180:1257-61; discussion 1261. 
40. Wang R, Wolf JS Jr, Wood DP Jr, et al. Accuracy of percutaneous core biopsy in management of small renal masses. Urology 2009;73:586-90; discussion 590-1.

41. Frank I, Blute ML, Cheville JC, et al. Solid renal tumours: An analysis of pathological features related to tumour size. J Urol 2003;170:2217-20.

42. Abel EJ, Carrasco A, Culp SH, et al. Limitations of preoperative biopsy in patients with metastatic renal cell carcinoma: Comparison to surgical pathology in 405 cases. BJU Int 2012; 110:1742-6.

43. Neuzillet $Y$, Lechevallier $E$, Andre $M$, et al. Accuracy and clinical role of fine needle percutaneous biopsy with computerized tomography guidance of small (less than $4.0 \mathrm{~cm}$ ) renal masses. J Urol 2004;171:1802-5.

44. Abel EJ, Culp SH, Matin SF, et al. Percutaneous biopsy of primary tumour in metastatic renal cell carcinoma to predict high risk pathological features: Comparison with nephrectomy assessment. I Urol 2010;184:1877-81. http://dx.doi.org/10.1016/i.juro.2010.06.105

45. Laguna MP, Kummerlin I, Rioja J, et al. Biopsy of a renal mass: Where are we now? Curr Opin Urol 2009; 19:447-53.

46. Leveridge MJ, Jewett MA. The role of percutaneous biopsies in management of small renal masses. In: Scardino PT, Linehan WM, Zelefsky MJ, Vogelzang NJ, Bochner BH, Sheinfeld J, editors. Comprehensive Textbook of Genitourinary Oncology. 4. New York: Lippincott Williams \& Wilkins; 2011.

47. Mullins JK, Rodriguez R. Renal cell carcinoma seeding of a percutaneous biopsy tract. Can Urol Assoc J 2013;7:E176-9

48. Boorijan S. Commentary on "Long-term survival following partial vs. radical nephrectomy among older patients with early-stage kidney cancer." Tan HJ, Norton, EC, Ye Z, Hafez KS, Gore JL, Miller DC, Dow Division of Health Services Research, Department of Urology, University of Michigan, Ann Arbor, MI: JAMA 2012;307(15):1629-35. Urol Oncol 2013;31:126-7. http://dx.doi.org/10.1016/i. urolonc.2012.11.004

49. Russo P. Oncological and renal medical importance of kidney-sparing surgery. Nat Rev Urol 2013;10:292-9.

50. Simone G, Papalia R, Guaglianone $S$, et al. 'Zero ischaemia', sutureless laparoscopic partial nephrectomy for renal tumours with a low nephrometry score. BJU Int 2012;110:124-30. http://dx.doi. org/10.1111/j.1464-410X.2011.10782.x

51. Favaretto RL, Sanchez-Salas R, Benoist N, et al. Oncologic outcomes after laparoscopic partial nephrectomy: mid-term results. J Endourol 2013;27:52-7.

52. Springer C, Veneziano D, Wimpissinger F, et al. Clampless laparoendoscopic single-site partial nephrectomy for renal cancer with low PADUA score: Technique and surgical outcomes. BJU Int 2013;111:1091-8. http://dx.doi.org/10.1111/i.1464-410X.2012.11601.x

53. Thomas AZ, Smyth L, Hennessey D, et al. Zero ischemia laparoscopic partial thulium laser nephrectomy. $J$ Endourol 2013;27:1366-70.

54. Gill IS, Patil MB, Abreu AL, et al. Zero ischemia anatomical partial nephrectomy: a novel approach. J Urol 2012;187:807-14. http://dx.doi.org/10.1016/i.juro.2011.10.146

55. Borofsky MS, Gill IS, Hemal AK, et al. Near-infrared fluorescence imaging to facilitate super-selective arteria clamping during zero-ischaemia robotic partial nephrectomy. BJU Int 2013;111:604-10. http://dx.doi. org/10.1111/i.1464-410X.2012.11490.x

56. Colli J, Sartor 0 , Grossman $L$, et al. Underutilization of partial nephrectomy for stage tl renal cell carcinoma in the United States, trends from 2000 to 2008. A long way to go. Clin Genitourin Cancer 2012;10:219-24. http://dx.doi.org/10.1016/i.lgc.2012.05.003

57. Huang WC, Levey AS, Serio AM, et al. Chronic kidney disease after nephrectomy in patients with renal cortical tumours: A retrospective cohort study. Lancet Oncol 2006;7:735-40.

58. Clark MA, Shikanov S, Raman JD, et al. Chronic kidney disease before and after partial nephrectomy. J Urol 2011;185:43-8. htrp://dx.doi.org/10.1016/i.juro.2010.09.019

59. Huang WC. Impact of nephron sparing on kidney function and non-oncologic mortality. Urol Onco 2010;28:568-74. http://dx.doi.org/10.1016/i.urolonc.2010.03.018

60. Bigot $P$, Bernhard JC, Crepel $M$, et al. How radical nephrectomy compares to partial nephrectomy for the treatment of pTla papillary renal cell carcinomas? [in French]. Prog Urol 2010;20:350-5.

61. Thompson RH, Kaag M, Vickers A, et al. Contemporary use of partial nephrectomy at a tertiary care center in the United States. J Urol 2009;181:993-7. http://dx.doi.org/10.1016/i.juro.2008.11.017

62. Minervini A, Serni $S$, Tuccio $A$, et al. Simple enucleation versus radical nephrectomy in the treatment of pTla and pTlb renal cell carcinoma. Ann Surg Oncol 2012;19:694-700. http://dx.doi.org/10.1245/ s10434-011-2003-x

63. Kates $M$, Badalato $G M$, Pitman $M$, et al. Increased risk of overall and cardiovascular mortality after radical nephrectomy for renal cell carcinoma $2 \mathrm{~cm}$ or less. J Urol 2011;186:1247-53. htrp://dx.doi. org/10.1016/i.juro.2011.05.054

64. Abouassaly R, Finelli A, Tomlinson GA, et al. How often are patients with diabetes or hypertension being treated with partial nephrectomy for renal cell carcinoma? A population-based analysis. BJU Int 2011;108:1806-12. http://dx.doi.org/10.1111/i.1464-410X.2011.10254.x

65. Sun $M$, Bianchi $M$, Hansen J, et al. Chronic kidney disease after nephrectomy in patients with small renal masses: a retrospective observational analysis. Eur Urol 2012;62:696-703. http://dx.doi. org/10.1016/i.eururo.2012.03.051
66. Wang AJ, Bhayani SB. Robotic partial nephrectomy versus laparoscopic partial nephrectomy for renal cell carcinoma: Single-surgeon andlysis of >100 consecutive procedures. Urology 2009;73:306-10. http:// dx.doi.org/10.1016/j.urology.2008.09.049

67. Ho H, Schwentner C, Neururer R, et al. Robotic-assisted laparoscopic partial nephrectomy: surgical technique and clinical outcomes at 1 year. BJU Int 2009;103:663-8. http://dx.doi.org/10.1111/j.1464410X.2008.08060.x

68. Eroglu M, Unsal A, Bakirtas $H$, et al. Routine frozen-section biopsy from the surgical bed should be performed during nephron-sparing surgery for renal cell carcinoma. Scand I Urol Nephrol 2005;39:222-5. http://dx.doi.org/10.1080/00365590510007757

69. Puppo $\mathrm{P}$, Introini $\mathrm{C}$, Calvi $\mathrm{P}$, et al. Long term results of excision of small renal cancer surrounded by a minimal layer of grossly normal parenchyma: Review of 94 cases. Eur Urol 2004;46:477-81. http:// dx.doi.org/10.1016/i.eururo.2004.07.007

70. Van Poppel H, Da Pozzo L, Albrecht W, et al. A prospective, randomised EORTC intergroup phase 3 study comparing the oncologic outcome of elective nephron-sparing surgery and radical nephrectomy for low-stage renal cell carcinoma. Eur Urol 2011;59:543-52. http://dx.doi.org/10.1016/i.eururo.2010.12.013

71. Go AS, Chertow GM, Fan D, et al. Chronic kidney disease and the risks of death, cardiovascular events, and hospitalization. N Eng/ J Med 2004;351:1296-305. http://dx.doi.org/10.1056/NEJMoa041031

72. Atwell $T D$, Schmit GD, Boorijan $S A$, et al. Percutaneous ablation of renal masses measuring $3.0 \mathrm{~cm}$ and smaller: Comparative local control and complications after radiofrequency ablation and cryoablation. AJR Am J Roentgenol 2013;200:461-6. http://dx.doi.org/10.2214/AJR.12.8618

73. Psutka SP, Feldman AS, McDougal WS, et al. Long-term oncologic outcomes after radiofrequency ablation for Tl renal cell carcinoma. Eur Urol 2013;63:486-92. http://dx.doi.org/10.1016/j. eururo.2012.08.062

74. Cadeddu JA. Re: Cryoablation vs radiofrequency ablation for the treatment of renal cell carcinoma: A metaanalysis of case series studies. J Urol 2013;189:70. http://dx.doi.org/10.1016/i.juro.2012.09.129

75. Zhao $X$, Wang $W$, Zhang $S$, et al. Improved outcome of percutaneous radiofrequency ablation in renal cell carcinoma: A retrospective study of intraoperative contrast-enhanced ultrasonography in 73 patients. Abdom Imaging 2012;37:885-91. http://dx.doi.org/10.1007/s00261-01 1-9828-4

76. El Dib R, Touma NJ, Kapoor A. Cryoablation vs radiofrequency ablation for the treatment of renal cell carcinoma: A meta-analysis of case series studies. BJU Int 2012;1 10:510-6. http://dx.doi.org/10.1111/ i.1464-410X.2011.10885.x

77. Kunkle DA, Uzzo RG. Cryoablation or radiofrequency ablation of the small renal mass: A meta-analysis. Cancer 2008;15:2671-80. http://dx.doi.org/10.1002/cncr.23896

78. Kunkle DA, Egleston BL, Uzzo RG. Excise, ablate or observe: The small renal mass dilemma-a metaanalysis and review. J Urol 2008;179:1227-33; discussion 1233-4. http://dx.doi.org/10.1016/i. juro.2007.11.047

79. Van Poppel H, Becker F, Cadeddu JA, et al. Treatment of localised renal cell carcinoma. Eur Urol 2011;60:662-72. http://dx.doi.org/10.1016/i.eururo.2011.06.040

80. Jewett MA, Mattar K, Basiuk J, et al. Active surveillance of small renal masses: Progression patterns of early stage kidney cancer. Eur Urol 2011;60:39-44. http://dx.doi.org/10.1016/i.eururo.2011.03.030

81. Kunkle DA, Crispen PL, Li T, et al. Tumour size predicts synchronous metastatic renal cell carcinoma: Implications for surveillance of small renal masses. J Urol 2007;177:1692-6; discussion 1697.

82. Mason RJ, Abdolell $M$, Trottier $G$, et al. Growth kinetics of renal masses: Analysis of a prospective cohort of patients undergoing active surveillance. Eur Urol 2011;59:863-7. http://dx.doi.org/10.1016/i. eururo.2011.02.023

83. Volpe A, Jewett MA. Current role, techniques and outcomes of percutaneous biopsy of renal tumours. Expert Rev Anticancer Ther 2009:9:773-83. http://dx.doi.org/10.1586/era.09.48

84. Leveridge MJ, Jewett MA. Recent developments in kidney cancer. Can Urol Assoc J 2011:5:195-203.

85. Wong JA, Rendon RA. Progression to metastatic disease from a small renal cell carcinoma prospectively followed with an active surveillance protocol. Can Urol Assoc J 2007;1:120-2.

86. Lane BR, Abouassaly $R, G a 0 ~ T$, et al. Active treatment of localized renal tumours may not impact overall survival in patients aged 75 years or older. Cancer 2010;116:3119-26. http://dx.doi.org/10.1002/ cncr. 25184

87. Staehler $M$, Haseke N, Stadler T, et al. Renal surgery in the elderly: Morbidity in patients aged $>75$ years in a contemporary series. BJU Int 2008;102:684-7. http://dx.doi.org/10.1111/i.1464410X.2008.07794.x

88. Motzer RJ, Russo P, Nanus DM, et al. Renal cell carcinoma. Curr Probl Cancer 1997;21:185-232. http:// dx.doi.org/10.1016/S0147-0272(97)80007-4

89. Russo P. Should elective partial nephrectomy be performed for renal cell carcinoma $>4 \mathrm{~cm}$ in size? Nat Clin Pract Urol 2008:5:482-3. http://dx.doi.org/10.1038/ncpurol 177

90. Leibovich BC, Blute ML, Cheville JC, et al. Nephron sparing surgery for appropriately selected renal cell carcinoma between 4 and $7 \mathrm{~cm}$ results in outcome similar to radical nephrectomy. J Urol 2004;171:1066-70.

91. Peycelon $M$, Hupertan V, Comperat $E$, et al. Long-term outcomes after nephron sparing surgery for renal cell carcinoma larger than 4 cm. J Urol 2009:181:35-41. http://dx.doi.org/10.1016/i.juro.2008.09.025 
Rendon et al.

92. Badalato GM, Kates $M$, Wisnivesky JP, et al. Survival after partial and radical nephrectomy for the treatment of stage TIbNOMO renal cell carcinoma (RCC) in the USA: A propensity scoring approach. BJU Int 2012;109:1457-62. http://dx.doi.org/10.1111/i.1464-410X.2011.10597.x

93. Thompson RH, Boorijan SA, Lohse CM, et al. Radical nephrectomy for pTla renal masses may be associated with decreased overall survival compared with partial nephrectomy. J Urol 2008;179:468. http:// dx.doi.org/10.1016/i.juro.2007.09.077

94. Mejean A. How far should partial nephrectomy be extended for renal cell carcinoma? [in French]. Ann Urol (Paris) 2006;40:S68-71. http://dx.doi.org/10.1016/S0003-4401 (06)80026-4

95. Russo P. Oncological outcomes of partial nephrectomy for renal carcinoma greater than $4 \mathrm{~cm}$. Curr Opin Urol 2011;21:362-7. http://dx.doi.org/10.1097/MOU.0b013e32834963ee

96. Sprenkle $\mathrm{PC}$, Power $\mathrm{N}$, Ghoneim $\mathrm{T}$, et al. Comparison of open and minimally invasive partial nephrectomy for renal tumours 4-7 centimeters. Eur Urol 2012;61:593-9. http://dx.doi.org/10.1016/i. eururo.2011.11.040

97. Van Poppel H, Joniau S, Goethuys $H$. Open partial nephrectomy for complex tumours and $>4 \mathrm{~cm}$ : Is it still the gold standard technique in the minimally invasive era? Arch Esp Urol 2013;66:129-38.

98. Masson-Lecomte A, Yates DR, Bensalah K, et al. Robot-assisted laparoscopic nephron sparing surgery for tumours over $4 \mathrm{~cm}$ : Operative results and preliminary oncologic outcomes from a multicentre French study. Eur J Surg Oncol 2013;39:799-803.

99. Gupta GN, Boris R, Chung $P$, et al. Robot-assisted laparoscopic partial nephrectomy for tumours greater than $4 \mathrm{~cm}$ and high nephrometry score: Feasibility, renal functional, and oncological outcomes with minimum 1 year follow-up. Urol Oncol 2013;31:51-6. http://dx.doi.org/10.1016/j.urolonc.2010.10.008

100. Erdem S, Tefik T, Mammadov A, et al. The use of self-retaining barbed suture for inner layer renorrhaphy significantly reduces warm ischemia time in laparoscopic partial nephrectomy: Outcomes of a matched-pair analysis. J Endourol 2013;27:452-8.

101. White WM, Goel RK, Haber GP, Kaouk JH. Robotic partial nephrectomy without renal hilar occlusion. BJU Int 2010;105:1580-4.

102. Lane BR, Campbell SC, Gill IS. 10-Year Oncological Outcomes After Laparoscopic and Open Partial Nephrectomy. J Urol 2013;190:44-9.

103. Fenn NJ, Gill IS. The expanding indications for laparoscopic radical nephrectomy. BJU Int 2004;94:761-5.

104. Zagoria RJ, Dyer RB, Wolfman NT, et al. Radiology in the diagnosis and staging of renal cell carcinoma. Crit Rev Diagn Imaging 1990;31:81-115.

105. Gervais DA, McGovern FJ, Arellano RS, et al. Radiofrequency ablation of renal cell carcinoma: part l, Indications, results, and role in patient management over a 6 -year period and ablation of 100 tumours. AJR Am J Roentgenol 2005; 185:64-71.

106. Zagoria RJ, Traver MA, Werle DM, et al. Oncologic efficacy of CT-guided percutaneous radiofrequency ablation of renal cell carcinomas. AJR Am J Roentgenol 2007;189:429-36.

107. Woldrich JM, Palazzi K, Stroup SP, et al. Trends in the surgical management of localized renal masses: Thermal ablation, partial and radical nephrectomy in the USA, 1998-2008. BJU Int 2013;111:1261-8.

108. Steinberg AP, Finelli A, Desai MM, et al. Laparoscopic radical nephrectomy for large (greater than $7 \mathrm{~cm}$, T2) renal tumours. J Urol 2004;172:2172-6.

109. Tanagho YS, Kaouk JH, Allaf ME, et al. Perioperative complications of robot-assisted partial nephrectomy: Analysis of 886 patients at 5 United States centers. Urology 2013;81:573-9.

110. Leslie S, Goh AC, Gill IS. Partial nephrectomy-contemporary indications, techniques and outcomes. Nat Rev Urol 2013;10:275-83.

111. Simmons MN, Chung BI, Gill IS. Perioperative efficacy of laparoscopic partial nephrectomy for tumours larger than $4 \mathrm{~cm}$. Eur Urol 2009;55:199-207.

112. Hung AJ, Cai J, Simmons MN, et al. "Trifecta" in partial nephrectomy. J Urol 2013;189:36-42.

113. Thompson RH, Lohse CM. Robotic-assisted Partial Nephrectomy: Excellent Intermediate Results for Those Who Follow Up. Eur Urol 2013;64:751-2.

114. Karellas ME, $O^{\prime} B$ rien MF, Jang TL, et al. Partial nephrectomy for selected renal cortical tumours of $>/=$ $7 \mathrm{~cm}$. BJU Int 2010;106:1484-7.

115. Long CJ, Canter DJ, Kutikov A, et al. Partial nephrectomy for renal masses $>/=7 \mathrm{~cm}$ : technical, oncological and functional outcomes. BJU Int 2012;109:1450-6.

116. Breau RH, Crispen PL, Jimenez RE, et al. Outcome of stage T2 or greater renal cell cancer treated with partial nephrectomy. J Urol 2010;183:903-8.

117. Bonsib SM. T2 clear cell renal cell carcinoma is a rare entity: A study of 120 clear cell renal cell carcinomas. J Urol 2005; 174:1199-202; discussion 1202.

118. Bertini $R$, Roscigno $M$, Freschi $M$, et al. The extent of tumour fat invasion affects survival in patients with renal cell carcinoma and venous tumour thrombosis. BJU Int 2011;108:820-4.

119. Kresowik TP, Johnson MT, Joudi FN. Combined renal sinus fat and perinephric fat renal cell carcinoma invasion has a worse prognosis than either alone. J Urol 2010;184:48-52.

120. Roos FC, Weirich J, Victor A, et al. Impact of several histopathological prognosticators and local tumour extension on oncological outcome in pT3b/c NOMO renal cell carcinoma. BJU Int 2009;104:461-9.

121. Bertini R, Roscigno M, Freschi M, et al. Renal sinus fat invasion in pT3a clear cell renal cell carcinoma affects outcomes of patients without nodal involvement or distant metastases. J Urol 2009;181:2027-32.
122. Thompson RH, Blute ML, Krambeck AE, et al. Patients with pT1 renal cell carcinoma who die from disease after nephrectomy may have unrecognized renal sinus fat invasion. Am I Surg Pathol 2007;31:1089-93.

123. Poon SA, Gonzalez JR, Benson MC, et al. Invasion of renal sinus fat is not an independent predictor of survival in pT3a renal cell carcinoma. BJU Int 2009; 103:1622-5.

124. Margulis V, Tamboli P, Matin SF, et al. Location of extrarenal tumour extension does not impact survival of patients with pT3a renal cell carcinoma. J Urol 2007;178:1878-82.

125. Bonsib SM. Renal veins and venous extension in clear cell renal cell carcinoma. Mod Pathol 2007;20:44-53.

126. Thompson RH, Leibovich BC, Cheville JC, et al. Should direct ipsilateral adrenal invasion from renal cell carcinoma be classified as pT3a? J Urol 2005;173:918-21.

127. Feifer A, Savage C, Rayala H, et al. Prognostic impact of muscular venous branch invasion in localized renal cell carcinoma cases. J Urol 2011;185:37-42.

128. Karlo CA, Di Paolo PL, Donati OF, et al. Renal cell carcinoma: role of MR imaging in the assessment of muscular venous branch invasion. Radiology 2013;267:454-9.

129. Abaza R, Angell J. Robotic Partial Nephrectomy for Renal Cell Carcinomas With Venous Tumour Thrombus. Urology 2013;81:1362-7.

130. Kim EH, Jain S, Benway BM, et al. Partial nephrectomy in two patients with known T3a tumours involving the renal vein. BJU Int 2012;109:1345-8.

131. Han KR, Bui MH, Pantuck AJ, et al. TNM T3a renal cell carcinoma: Adrenal gland involvement is not the same as renal fat invasion. J Urol 2003; 169:899-903; discussion 904.

132. Boorijan SA, Sengupta S, Blute ML. Renal cell carcinoma: Vena caval involvement. BJU Int 2007;99:1239-44.

133. Whitson JM, Reese AC, Meng MV. Population based analysis of survival in patients with renal cell carcinoma and venous tumour thrombus. Urol Oncol 2013;31:259-63.

134. Habboub HK, Abu-Yousef MM, Williams RD, et al. Accuracy of color Doppler sonography in assessing venous thrombus extension in renal cell carcinoma. AJR Am J Roentgenol 1997;168:267-71.

135. Narumi Y, Hricak H, Presti JC Jr, et al. MR imaging evaluation of renal cell carcinoma. Abdom Imaging 1997;22:216-25.

136. Granberg CF, Boorijan SA, Schaff HV, et al. Surgical management, complications, and outcome of radical nephrectomy with inferior vena cava tumour thrombectomy facilitated by vascular bypass. Urology 2008;72:148-52.

137. Molina AM, Motzer RJ. Clinical practice guidelines for the treatment of metastatic renal cell carcinoma: today and tomorrow. Oncologist 2011;16(Supp|2):45-50.

138. Russo $P, O^{\prime} B$ rien MF. Surgical intervention in patients with metastatic renal cancer: metastasectomy and cytoreductive nephrectomy. Urol Clin North Am 2008;35:679-86.

139. Gonzalez J, Gorin MA, Garcia-Roig M, et al. Inferior vena cava resection and reconstruction: Technical considerations in the surgical management of renal cell carcinoma with tumour thrombus. Urol Oncol 2014;32:34.e19-26. Epub 2013 Mar 15.

140. Karnes RJ, Blute ML. Surgery insight: Management of renal cell carcinoma with associated inferior vena cava thrombus. Nat Clin Pract Urol 2008;5:329-39.

141. Blute ML, Leibovich BC, Lohse CM, et al. The Mayo Clinic experience with surgical management, complications and outcome for patients with renal cell carcinoma and venous tumour thrombus. BJU Int 2004;94:33-41.

142. Steinnerd LE, Vardi IY, Bhayani SB. Laparoscopic radical nephrectomy for renal carcinoma with known level I renal vein tumour thrombus. Urology 2007;69:662-5.

143. Hammond L, Powell TM, Schwartz BF. Pure laparoscopic radical nephrectomy for stage $T(3 b)$ renal-cell carcinoma: more than 2-year follow-up. J Endourol 2007;21:408-10.

144. Kapoor A, Nguan C, Al-Shaiii TF, et al. Laparoscopic management of advanced renal cell carcinoma with level I renal vein thrombus. Urology 2006;68:514-7.

145. Slojewski M, Golab A, Petrasz P, et al. Laparoscopic radical nephrectomy for T3b tumour. J Laparoendosc Adv Surg Tech A 2010;20:47-9.

146. Hoang AN, Vaporcyian AA, Matin SF. Laparoscopy-assisted radical nephrectomy with inferior vena caval thrombectomy for level III to III tumour thrombus: A single-institution experience and review of the literature. J Endourol 2010;24:1005-12.

147. Metcalfe C, Chang-Kit L, Dumitru I, et al. Antegrade balloon occlusion of inferior vena cava during thrombectomy for renal cell carcinoma. Can Urol Assoc J 2010;4:E105-8.

148. Choueiri TK, Xie W, Kollmannsberger $C$, et al. The impact of cytoreductive nephrectomy on survival of patients with metastatic renal cell carcinoma receiving vascular endothelial growth factor targeted therapy. J Urol 2011;185:60-6.

149. Stroup SP, Raheem OA, Palazzi KL, et al. Does timing of cytoreductive nephrectomy impact patient survival with metastatic renal cell carcinoma in the tyrosine kinase inhibitor era? A multi-institutional study. Urology 2013;81:805-11.

150. Zisman A, Pantuck AJ, Chao DH, et al. Renal cell carcinoma with tumour thrombus: Is cytoreductive nephrectomy for advanced disease associated with an increased complication rate? J Urol 2002;168:9627. http://dx.doi.org/10.1016/S0022-5347(05)64552-1

151. Kletscher BA, Qian J, Bostwick DG, et al. Prospective analysis of the incidence of ipsilateral adrenal metastasis in localized renal cell carcinoma. J Urol 1996;155:1844-6. http://dx.doi.org/10.1016/ S0022-5347(01)66026-9 
152. Yap SA, Alibhai SM, Abouassaly R, et al. Do we continue to unnecessarily perform ipsilateral adrenalectomy at the time of radical nephrectomy? A population based study. J Urol 2012;187:398-404.

153. Tsui KH, Shvarts 0 , Barbaric $Z$, et al. Is adrenalectomy a necessary component of radical nephrectomy? UCLA experience with 511 radical nephrectomies. J Urol 2000;163:437-41.

154. Jewett M, Finelli A, Kollmannsberger C, et al. Management of kidney cancer: canadian kidney cancer forum consensus update 2011. Can Urol Assoc J 2012;6:16-22.

155. Blom JH, van Poppel H, Marechal JM, et al. Radical nephrectomy with and without lymph-node dissection: Final results of European Organization for Research and Treatment of Cancer (EORTC) randomized phase 3 trial 30881. Eur Urol 2009;55:28-34. http://dx.doi.org/10.1016/i.eururo.2008.09.052

156. Canfield SE, Kamat AM, Sanchez-Ortiz RF, et al. Renal cell carcinoma with nodal metastases in the absence of distant metastatic disease (clinical stage TxN1-2MO): The impact of aggressive surgical resection on patient outcome. J Urol 2006; 175:864-9.

157. Pantuck AJ, Zisman A, Dorey F, et al. Renal cell carcinoma with retroperitoneal lymph nodes: role of lymph node dissection. J Urol 2003;169:2076-83.

158. Kenney PA, Wood CG. Integration of surgery and systemic therapy for renal cell carcinoma. Urol Clin North Am 2012;39:211-31

159. Cowey CL, Amin C, Pruthi RS, et al. Neoadjuvant clinical trial with sorafenib for patients with stage II or higher renal cell carcinoma. J Clin Oncol 2010;28:1502-7.

160. Thomas AA, Rini BI, Lane BR, et al. Response of the primary tumour to neoadjuvant sunitinib in patients with advanced renal cell carcinoma. J Urol 2009;181:518-23; discussion 523.

161. Jonasch E, Wood CG, Matin SF, et al. Phase II presurgical feasibility study of bevacizumab in untreated patients with metastatic renal cell carcinoma. J Clin Oncol 2009;27:4076-81.

162. Abel EJ, Culp SH, Tannir NM, et al. Primary tumour response to targeted agents in patients with metastatic renal cell carcinoma. Eur Urol 2011;59:10-5. hittp://dx.doi.org/10.1016/i.eururo.2010.09.034

163. Jonasch E, Tannir NM. Targeted therapy for locally advanced renal cell carcinoma. Target Oncol 2010:5:113-8

164. Ficarra V, Novara G. Kidney cancer: Neoadjuvant targeted therapies in renal cell carcinoma. Nat Rev Cancer 2010;7:63-4.

165. Silberstein JL, Millard F, Mehrazin R, et al. Feasibility and efficacy of neoadjuvant sunitinib before nephron-sparing surgery. BJU Int 2010;106:1270-6.

166. Cost NG, Delacroix SE Jr, Sleeper JP, et al. The impact of targeted molecular therapies on the level of renal cell carcinoma vena caval tumour thrombus. Eur Urol 2011;59:912-8.

167. Powles T, Kayani I, Blank C, et al. The safety and efficacy of sunitinib before planned nephrectomy in metastatic clear cell renal cancer. Ann Oncol 2011;22:1041-7.

168. Powels T, Bex A. Integration of surgery in metastatic renal cancer. In: Campbell S, Rini B, editors. Renal Cell Carcinoma: Clinical Management. New York: Springer Science; 2013:257-7. http://dx.doi. org/10.1007/978-1-62703-062-5_15

169. Chapin BF, Delacroix SE Jr, Culp SH, et al. Safety of presurgical targeted therapy in the setting of metastatic renal cell carcinoma. Eur Urol 2011:60:964-71.

170. Escudier B. Benefit of cytoreductive nephrectomy in metastatic RCC: do we learn from retrospective studies and small prospective studies? Ann Oncol 2011;22:995-6.

171. Kjaer M, Frederiksen PL, Engelholm SA. Postoperative radiotherapy in stage II and III renal adenocarcinoma. A randomized trial by the Copenhagen Renal Cancer Study Group. Int J Radiat Oncol Biol Phys 1987;13:665-72.

172. Finney $\mathrm{R}$. The value of radiotherapy in the treatment of hypernephroma-a clinical trial. $\mathrm{Br} J \mathrm{Urol}$ 1973; 45:258-69.

173. Pizzocaro G, Piva L, Colavita M, et al. Interferon adjuvant to radical nephrectomy in Robson stages II and III renal cell carcinoma: a multicentric randomized study. J Clin Oncol 2001;19:425-31.

174. Messing EM, Manola J, Wilding G, et al. Phase III study of interferon alfa-NL as adjuvant treatment for resectable renal cell carcinoma: An Eastern Cooperative Oncology Group/Intergroup trial. J Clin Oncol 2003;21:1214-22.

175. Galligioni E, Quaia M, Merlo A, et al. Adjuvant immunotherapy treatment of renal carcinoma patients with autologous tumour cells and bacillus Calmette-Guerin: Five-year results of a prospective randomized study. Cancer 1996;77:2560-6.

176. Clark JI, Atkins MB, Urba WJ, et al. Adjuvant high-dose bolus interleukin-2 for patients with high-risk renal cell carcinoma: A cytokine working group randomized trial. J Clin Oncol 2003;21:3133-40.

177. Jocham D, Richter A, Hoffmann L, et al. Adjuvant autologous renal tumour cell vaccine and risk of tumour progression in patients with renal-cell carcinoma after radical nephrectomy: phase III, randomised controlled trial. Lancet 2004;363:594-9.

178. Margulis V, Sanchez-Ortiz RF, Tamboli P, et al. Renal cell carcinoma clinically involving adjacent organs: Experience with aggressive surgical management. Cancer 2007;109:2025-30.

179. Frank I, Blute ML, Cheville JC, et al. An outcome prediction model for patients with clear cell renal cell carcinoma treated with radical nephrectomy based on tumour stage, size, grade and necrosis: the SSIGN score. J Urol 2002;168:2395-400. http://dx.doi.org/10.1016/S0022-5347(05)64153-5

180. Sorbellini M, Kattan MW, Snyder ME, et al. A postoperative prognostic nomogram predicting recurrence for patients with conventional clear cell renal cell carcinoma. J Urol 2005;173:48-51.
181. Zisman A, Pantuck AJ, Dorey F, et al. Improved prognostication of renal cell carcinoma using an integrated staging system. J Clin Oncol 2001;19:1649-57.

182. Bekema HJ, Maclennan S, Imamura M, et al. Systematic review of adrenalectomy and lymph node dissection in locally advanced renal cell carcinoma. Eur Urol 2013;64:799-810.

183. Blute ML, Leibovich BC, Cheville JC, et al. A protocol for performing extended lymph node dissection using primary tumour pathological features for patients treated with radical nephrectomy for clear cell renal cell carcinoma. J Urol 2004;172:465-9. http://dx.doi.org/10.1097/01.ju.0000129815.91927.85

184. Studer UE, Scherz S, Scheidegger J, et al. Enlargement of regional lymph nodes in renal cell carcinoma is often not due to metastases. J Urol 1990;144:243-5.

185. Leibovich BC, Cheville JC, Lohse CM, et al. A scoring algorithm to predict survival for patients with metastatic clear cell renal cell carcinoma: A stratification tool for prospective clinical trials. J Urol 2005; 174:175963; discussion 1763.

186. Naito S, Yamamoto N, Takayama T, et al. Prognosis of Japanese metastatic renal cell carcinoma patients in the cytokine era: A cooperative group report of 1463 patients. Eur Urol 2010;57:317-25.

187. Vogl UM, Zehetgruber $H$, Dominkus $M$, et al. Prognostic factors in metastatic renal cell carcinoma: Metastasectomy as independent prognostic variable. Br J Cancer 2006;95:691-8. http://dx.doi. org/10.1038/si.bic.6603327

188. Kavolius JP, Mastorakos DP, Pavlovich C, et al. Resection of metastatic renal cell carcinoma. J Clin Oncol 1998;16:2261-6.

189. van der Poel HG, Roukema JA, Horenblas S, et al. Metastasectomy in renal cell carcinoma: A multicenter retrospective analysis. Eur Urol 1999;35:197-203. http://dx.doi.org/10.1159/000019849

190. Daliani DD, Tannir NM, Papandreou CN, et al. Prospective assessment of systemic therapy followed by surgical removal of metastases in selected patients with renal cell carcinoma. BJU Int 2009;104:456-60. http://dx.doi.org/10.1111/j.1464-410X.2009.08490.x

191. Kwak C, Park YH, Jeong CW, et al. No role of adjuvant systemic therapy after complete metastasectomy in metastatic renal cell carcinoma? Urol Oncol 2007;25:310-6. http://dx.doi.org/10.1016/j. urolonc.2006.08.022

192. Breau RH, Blute ML. Surgery for renal cell carcinoma metastases. Curr Opin Urol 2010;20:375-81.

193. Jackson RJ, Loh SC, Gokaslan ZL. Metastatic renal cell carcinoma of the spine: surgical treatment and results. J Neurosurg 2001;94(1Suppl):18-24.

194. Flanigan RC, Mickisch G, Sylvester R, et al. Cytoreductive nephrectomy in patients with metastatic renal cancer: a combined analysis. J Urol 2004;171:1071-6. http://dx.doi.org/10.1097/01. ju.0000110610.61545.ae

195. Mickisch GH, Garin A, van Poppel H, et al. Radical nephrectomy plus interferon-alfa-based immunotherapy compared with interferon alfa alone in metastatic renal-cell carcinoma: A randomised trial. Lancet 2001;358:966-70

196. Marcus SG, Choyke PL, Reiter R, et al. Regression of metastatic renal cell carcinoma after cytoreductive nephrectomy. J Urol 1993; 150:463-6.

197. Motzer RJ, Michaelson MD, Rosenberg J, et al. Sunitinib efficacy against advanced renal cell carcinoma. J Urol 2007;178:1883-7.

198. Escudier B, Eisen T, Stadler WM, et al. Sorafenib for treatment of renal cell carcinoma: Final efficacy and safety results of the phase III treatment approaches in renal cancer global evaluation trial. J Clin Oncol 2009;27:3312-8.

199. Choueiri TK, Xie W, Kollmannsberger C, et al. The impact of cytoreductive nephrectomy on survival of patients with metastatic renal cell carcinoma receiving vascular endothelial growth factor targeted therapy. J Urol 2011;185:60-6. http://dx.doi.org/10.1016/i.juro.2010.09.012

200. Fallick ML, MCDermott DF, LaRock D, et al. Nephrectomy before interleukin-2 therapy for patients with metastatic renal cell carcinoma. J Urol 1997;158:1691-5. http://dx.doi.org/10.1016/S0022$5347(01) 64097-7$

201. Sun M, Abdollah F, Shariat SF, et al. Propensity-score matched comparison of complications, blood transfusions, length of stay, and in-hospital mortality between open and laparoscopic partial nephrectomy: a national series. Eur I Surg Oncol 2012;38:80-7.

202. Abdollah F, Sun M, Thuret R, et al. Mortality and morbidity after cytoreductive nephrectomy for metastatic renal cell carcinoma: A population-based study. Ann Surg Oncol 2011;18:2988-96. http://dx.doi. org/10.1245/s10434-011-1715-2

203. Margulis V, Shariat SF, Rapoport Y, et al. Development of accurate models for individualized prediction of survival after cytoreductive nephrectomy for metastatic renal cell carcinoma. Eur Urol 2013;63:947-52. http://dx.doi.org/10.1016/i.eururo.2012.11.040

204. Culp SH, Tannir NM, Abel EJ, et al. Can we better select patients with metastatic renal cell carcinoma for cytoreductive nephrectomy? Cancer 2010;1 16:3378-88. http://dx.doi.org/10.1002/cncr.25046

205. Eggener SE, Yossepowitch 0, Pettus JA, et al. Renal cell carcinoma recurrence after nephrectomy for localized disease: predicting survival from time of recurrence. J Clin Oncol 2006;24:3101-6.

206. Murthy SC, Kim K, Rice TW, et al. Can we predict long-term survival after pulmonary metastasectomy for renal cell carcinoma? Ann Thorac Surg 2005;79:996-1003. http://dx.doi.org/10.1016/i.athoracsur.2004.08.034 
Rendon et al.

207. Friedel $G$, Hurtgen $M$, Penzenstadler $M$, et al. Resection of pulmonary metastases from renal cell carcinoma Anticancer Res 1999;19:1593-6.

208. Pfannschmidt J, Hoffmann H, Muley T, et al. Prognostic factors for survival after pulmonary resection of metastatic renal cell carcinoma. Ann Thorac Surg 2002;74:1653-7. http://dx.doi.org/10.1016/ S0003-4975(02)03803-1

209. Piltz S, Meimarakis G, Wichmann MW, et al. Long-term results after pulmonary resection of renal cell carcinoma metastases. Ann Thorac Surg 2002;73:1082-7. http://dx.doi.org/10.1016/S00034975(01)03602-5

210. Cerfolio RJ, Allen MS, Deschamps C, et al. Pulmonary resection of metastatic renal cell carcinoma. Ann Thorac Surg 1994;57:339-44. http://dx.doi.org/10.1016/0003-4975(94)90994-6

211. Hofmann HS, Neef $H$, Krohe K, et al. Prognostic factors and survival after pulmonary resection of metastatic renal cell carcinoma. Eur Urol 2005;48:77-81; discussion 82.

212. Kollender Y, Bickels J, Price WM, et al. Metastatic renal cell carcinoma of bone: Indications and technique of surgical intervention. J Urol 2000;164:1505-8. http://dx.doi.org/10.1016/S0022-5347 (05)67016-4

213. Adiga GU, Dutcher JP, Larkin M, et al. Characterization of bone metastases in patients with renal cell cancer. BJU Int 2004;93:1237-40. http://dx.doi.org/10.1111/j.1464-410X.2004.04849.x

214. Lin PP, Mirza AN, Lewis V0, et al. Patient survival after surgery for osseous metastases from renal cell carcinoma. J Bone Joint Surg Am 2007;89:1794-801. hitp://dx.doi.org/10.2106/JBJS.F.00603

215. Jung ST, Ghert MA, Harrelson JM, et al. Treatment of osseous metastases in patients with renal cell carcinoma. Clin Orthop Relat Res 2003:223-31.

216. Reddy S, Wolfgang CL. The role of surgery in the management of isolated metastases to the pancreas. Lancet Oncol 2009;10:287-93. http://dx.doi.org/10.1016/S1470-2045(09)70065-8

217. Antonelli A, Cozzoli A, Simeone C, et al. Surgical treatment of adrenal metastasis from renal cell carcinoma: A single-centre experience of 45 patients. BJU Int 2006;97:505-8. http://dx.doi.org/10.1111/j.1464410X.2006.05934.x
218. Kim SH, Brennan MF, Russo $\mathrm{P}$, et al. The role of surgery in the treatment of clinically isolated adrenal metastasis. Cancer 1998;82:389-94. http://dx.doi.org/10.1002/(SICI) 10970142(19980115)82:2<395::AID-CNCR20>3.0.C0;2-T

219. Kutikov A, Fossett LK, Ramchandani P, et al. Incidence of benign pathologic findings at partial nephrectomy for solitary renal mass presumed to be renal cell carcinoma on preoperative imaging. Urology 2006;68:737-40. http://dx.doi.org/10.1016/i.urology.2006.04.01

220. Stakhovskyi 0, Yap SA, Leveridge M, et al. Small renal mass: What the urologist needs to know for treatment planning and assessment of treatment results. AJR Am J Roentgenol 2011;196:1267-73.

221. Truesdale CM, Soulen MC, Clark TW, et al. Percutaneous computed tomography-guided renal mass radiofrequency ablation versus cryoablation: Doses of sedation medication used. J Vasc Interv Radiol 2013;24:347-50.

222. Tan YK, Best SL, Olweny E, et al. Radiofrequency ablation of incidental benign small renal mass: Outcomes and follow-up protocol. Urology 2012;79:827-30.

223. Kunkle DA, Uzzo RG. Cryoablation or radiofrequency ablation of the small renal mass: A meta-analysis. Cancer 2008;113:2671-80. http://dx.doi.org/10.1002/cncr.23896

224. Kassouf W, Siemens R, Morash C, et al. Follow-up guidelines after radical or partial nephrectomy for localized and locally advanced renal cell carcinoma. Can Urol Assoc J 2009;3:73-6.

Correspondence: Dr. Ricardo A. Rendon, Queen Elizabeth II Health Sciences Centre, Room 210, 5-South, Victoria Building, 1276 South Park St., Halifax, NS B3H 2Y9; fax: 902 492-2437; rrendon@dal.ca 